\title{
THE DIACHRONIC ANALYSIS OF PASTORALISM THROUGH COMPARATIVE VARIABLES ${ }^{1}$
}

\author{
Lucia Nixon and Simon Price
}

(from Annual of the British School at Athens 96: 395-424) 
The Diachronic Analysis of Pastoralism through Comparative Variables

ABSTRACT

Diachronic analyses of pastoralism over the millennia pose a problem. Studies of one period can use models based on other periods as heuristic devices, to pose problems and questions for investigation. But survey archaeologists and others engaged in diachronic analysis cannot assume a period-specific model as a starting point. Instead, we propose that investigation begin from a set of seven variables, which constitute the elements for the formulation of comparative analyses: environment; location; scale; specialisation; links with agriculture; gender/division of labour; and cultural integration. The first five have been discussed before in the literature, but the last two have not previously been given sufficient attention, because of the old dominance of environmental and economic preoccupations. 
Transhumance in the Mediterranean has long been studied, by scholars working in very different disciplines. Interest began among ethnographers and historians. For example, Wace and Thompson presented a detailed account of the contemporary movements of the Vlachs between their summer villages in the Pindus mountains of northern Greece down to their winter villages in the plains of Thessaly and Macedonia; ${ }^{2}$ and historians have exploited the extensive documentary evidence for Castilian transhumance of the Middle Ages ${ }^{3}$ or for transhumance in the Pontus of northern Turkey in the Byzantine period. ${ }^{4}$ More recently, archaeologists have investigated material aspects of modern transhumance. Building on early ethnographic studies, such as the documentation of transhumance in central Crete by the Cretan scholar Xanthoudidis, more formal ethnoarchaeological studies have been undertaken in other parts of Crete and Greece, ${ }^{5}$ as well as Spain, Italy and Turkey. ${ }^{6}$ Archaeologists have also sought to identify remains of ancient transhumant sites. ${ }^{7}$ Social anthropologists have included transhumance and cheese-making in their general studies of remote villages in southern France and Switzerland. ${ }^{8}$

There have been three pitfalls in such studies of transhumance. The first is to privilege transhumance at the expense of other, less picturesque forms of pastoralism. In fact, transhumance is, in some periods, a highly marginal activity, and the important issue is the circumstances that can favour it over other forms of pastoralism. ${ }^{9}$

A related danger is the assumption of a Braudelian longue durée. ${ }^{10}$ Some take transhumance to be one of the slow-moving rhythms of the Mediterranean; the processes of change are indeed so slow that evidence about present pastoral practices can safely be projected back onto the past. But it is a romantic temptation, which must be resisted, to imagine that the rhythms of rural life in Greece are unchanging through the centuries and indeed millennia. ${ }^{11}$ This temptation is particularly strong for archaeologists attempting to investigate transhumance in the past: romantic encounters with modern shepherding practices form the unexamined basis for models for ancient pastoralism. In fact, simple retrojection of present practices has to be avoided at all costs. It forms a vicious circle of interpretation, which prevents any discovery that the past was different from the present. ${ }^{12}$

A third danger has been to remain within the bounds of one academic discipline and 
consequently to privilege one type of information (ethnographic, documentary or archaeological). And yet the historian who uses documents to plot transhumance routes on the map without wondering about the material aspects of transhumance may be misled by the documents and may miss the actual workings of the process. Conversely, the anthropologist studying animal thefts by shepherds needs to study not only the rhetoric of the shepherds' stories, but also the underlying issue of the competition for grazing resources. ${ }^{13}$

Such pitfalls are perfectly understandable: urban scholars are naturally attracted by the exotic; projection back of models based on present practices offers an attractive basis for understanding the past; and working within one discipline helpfully limits the number of potential sources and approaches. But of course all three pitfalls are also bars to a fuller understanding. One way forward has been provided by the development of survey archaeology, which examines whole landscapes over long periods of time. The longue durée is one of the very real strengths of survey archaeology, which can be very good at what one might call 'enforced consistency': if it is good for one period, it is good for all of them. Thus if looking at pottery shapes can tell us something about site function in the Bronze Age, it can provide equally useful information for the eighteenth century AD. Survey archaeology has also been at the forefront of the move to break down disciplinary boundaries and characteristically avoids privileging one kind of information over another - for example, assuming that written evidence is always better than material. In other words, surveys use all types of evidence archaeological, documentary, and ethnographic or anthropological - and put them in the context of the local environment. ${ }^{14}$ They are thus engaged in a form of comparative history, comparing patterns and developments in one region in different epochs.

The assumption of such studies is not that nothing changes, nor that there is a 'natural' use of the landscape which is independent of climatic, social, economic or political changes. Rather, survey archaeology explores how human uses of the (potentially changing) landscape have differed in different periods. In other words, it is committed to a strong diachronic analysis, which also brings out elements common to different periods. One of the advantages of enforced consistency in serious diachronic work is that the results can then be used to make truly 
diachronic comparisons, e.g. the same site or the same region in different periods; cooking vessels from Minoan tripod cooking pots to traditional Greek tsoukalia; patterns of imports and exports; and economic practices such as pastoralism, transhumant or otherwise.

Undertaking diachronic analyses over the millennia, which is a form of comparative history, has to be done with great care. Studies of one period can use models based on other periods as heuristic devices, to pose problems and questions for investigation. But those engaged in comparative history, whether synchronic or diachronic, cannot assume a secure period-specific model as a starting point. Indeed, a comparative history has to be interested equally in all the cases under consideration. In addition, comparative historians have to ensure that they are comparing like with like, and that cases are not compared simply because they have been given the same label by scholars. ${ }^{15}$ We propose as a solution to these two methodological injunctions that the comparison of pastoralism (whether synchronic or diachronic) be made using a set of analytic factors. The seven factors proposed here are not specific to periods or places, and are deliberately broad, so as to ensure useful comparability between very different kinds of information (material; written; directly observed), over long, as well as short, periods of time.

The seven factors we propose in the analysis of pastoralism are: environment; location; scale; specialisation in products; links with agriculture; gender and the division of labour; and cultural integration. The first five have been discussed before in the literature, but the last two have not previously been given sufficient attention, because of the old dominance (especially in processual archaeology) of environmental and economic preoccupations. In our opinion it is important to include factors such as gender and the division of labour, and cultural integration because such factors often play a crucial role in defining other, more 'processual' categories. In diachronic analysis, each factor should be examined for each of the periods of the systems examined; evidence may be lacking for particular periods, but the discipline of having to look is rewarding, if only because the new questions that arise can be investigated, and sometimes answered. In addition, it is in the context of particular case-studies that the interaction of the seven variables can and should be examined. 
These seven analytic factors are not specific to time or place, but in considering each of them we make reference to a number of systems of pastoralism, chiefly in the Mediterranean, and more particularly in Greece. ${ }^{16}$ We also present a pair of specific examples to show the value of a diachronic comparative approach, based on two of the most mountainous areas of Greece: Sphakia, SW Crete (fig. 1; Map 1); and the Pindus Mountains, NW Greece (fig.2; Map 2).

In fig.1, we look at transhumant pastoralism in the deme, formerly eparchy (administrative district) of Sphakia, using information collected by members of the Sphakia Survey. Sphakia (c. $470 \mathrm{~km}^{2}$ ) includes most of the White Mountains, as well as most of the upland area still used for summer pastures, the Madhares, and some 10-12 gorges, including the Samaria Gorge. As a result of systematic archaeological survey work we have identified some 315 sites, ranging from Final Neolithic/Early Minoan to the end of the Turkish period (c. 3500 BC - AD 1900). We have also recorded information about the late twentieth century version of transhumance, which differs in several important ways from traditional practice. We do not, however, assume the existence of transhumance in every period simply because we have observed it in action today; indeed it has always been quite clear that even in this rugged landscape environmental determinism does not apply, and that human responses to, and exploitation of, the Sphakiote environment have varied greatly over time. ${ }^{17}$ In several periods the landscape of Sphakia is used not in discrete environmental units, but in broad north-south slices. Fig. 1 focuses on one such slice, incorporating the three altitudes common to most (up, middle, and down). In this case, up is in the Madhares; middle is usually in Anopoli on the south side of the White Mountains, but in some periods may also be in the Theriso area on the north; and down is at Loutro, ancient Phoenix. ${ }^{18}$ The chart in fig. 1 spans some 5000 years, divided into four periods of uneven length: Prehistoric (PH, c. 3500 - 1050 BC); GeometricArchaic-Classical-Hellenistic-Roman (GACHR, c. 1050 BC - AD 700); Byzantine-VenetianTurkish (BVT, i.e. the Second Byzantine period on Crete, c. AD 700 - 1900); and the twentieth century. Of course, within each of these long periods there were changes, which cannot be discussed here. The final paper publication of the Sphakia data will also show the interaction of our seven variables within each of the periods; it will also allow for changes within each of the 
periods, which cannot be done here. ${ }^{19}$

Fig. 2 tabulates the data from three independent studies of transhumance in NW Greece, where people speaking Vlach, a Balkan language descended from Latin, traditionally moved from lowland winter settlements and villages in Thessaly to summer villages on the E slopes of the Pindus Mountains, and back again each year. The three studies of Vlach transhumance used here were made by three different groups of scholars from different backgrounds at three different times during the twentieth century. Wace and Thompson describe themselves as inquisitive historians; they accompanied the Vlachs in their eight-day journey from Tirnavo to Samarina in 1910, with a return visit to Samarina the following year, at a time when the system of transhumance was already beginning to unravel. ${ }^{20}$ Sivignon conducted his geographic research in 1967, incorporating much statistical information about the period immediately after World War II. ${ }^{21}$ Chang, sometimes in conjunction with Tourtellotte, has done ethnoarchaeological work on contemporary pastoral sites as part of the Grevena Survey Project since $1988 .^{22}$ The three studies were thus conducted for different reasons, and with different questions in mind. Together, their work permits us to compare transhumant pastoralism in the Pindus during the past century. The Vlach pastoralists were only one of three groups using the Pindus. The others were the Sarakatsanoi, pure pastoralists, and those occupying mountain villages year-round and primarily farming, though also keeping small numbers of sheep, goats and cows. $^{23}$

The two charts use the seven analytic factors to compare transhumance in Sphakia and the Pindus. In our opinion, each provides a useful local comparison, and together they demonstrate the value of the comparative approach for long and short periods of time.

\section{ENVIRONMENT}

Obviously the physical environment has to come first. As there is always a need to provide a year-round supply of water and food for animals, some degree of mobility is normally necessary: the ancient Greek word probata, which originally meant livestock in general and came to refer specifically to sheep (as in modern Greek), means etymologically 'that which 
moves before'.$^{24}$ The image of mobile grazing is built into the Greek word. What sort of grazing depends on the specific environment, whose variables provide the potential for human exploitation. $^{25}$ It is the relative proximity of winter pastures on the south coast of Turkey to summer pastures in the hills to the north that offers the possibility of transhumance. ${ }^{26}$ Similarly, the mountains of central Italy can be used by pastoralists of coastal areas. ${ }^{27}$ In fact in numerous parts of the world, from the Swiss Alps to the mountains of Peru, climatic variations either because of altitude or of latitude are sufficiently pronounced to be useful for humans. The issue is the significance of such variations: do they determine transhumant pastoralism or are they merely preconditions for it? Studies, whether archaeological, historical or anthropological, sometimes assume that environmental constraints are the only reason for medium or large scale transhumant pastoralism, that is, there is an environmentally determined longue durée of transhumance. $^{28}$ On the other hand studies which have sufficient time-depth emphasise the importance of other factors (such as the ones discussed below): the environment is a resource which people have chosen to exploit in different ways at different times. ${ }^{29}$ The extent of compression of the landscape does make a difference. Sphakia, for example, has an extraordinary altitudinal and environmental range. On the coast there are palm trees, but only $16 \mathrm{~km}$ away lie the White Mountains and Mt Pakhnes $(2452 \mathrm{~m})$, the highest mountain on Crete, where there is snow even in summer. The proximity of the mountains to the sea means that the environmental zones which elsewhere spread over a considerable distance are here enormously compressed. The closer the proximity of different environmental zones, the easier it is to exploit the full range of zones, but such proximity offers only the possibility of such exploitation; it does not require it. ${ }^{30}$

In addition, the environment itself is not unchanging, and cannot be assumed to offer a set of possibilities constant over time. Over the last 5000 years of Mediterranean history there have been periods of warmer wetter weather and cooler drier weather, such as the wetter conditions on Crete down to the end of the Early Bronze Age or the European Little Ice Age between the 1590 s and 1690 s, running up to c. 1850 . The effects of these changes are noticeable even in lowland zones: for example, Frost Fairs on the Thames in London in 1608 and 1648-9. ${ }^{31}$ 
But the effects will be magnified at the climatic margins, that is in the upland terrains which provide the summer pastures. If the weather turns significantly colder, the summer gap between the snows will shorten and perhaps disappear altogether. At some periods, then, the summer pastures which we take for granted today will not have existed; transhumance, if it was viable at all, will have been practised within a more constricted environmental range. In other periods the incidence of disastrous winters will have increased: in Italy in 1611-12, for example, bad weather killed $69 \%$ of the sheep. ${ }^{32}$ Other changes in the environment are attributable to human intervention, but may have equally dramatic effects on the possibilities of transhumance. Access to lowlands is often important for winter grazing. As for long periods coastal lowlands have been water-logged (and sometimes malarial) and hence little used for human settlements, such access has often not been a problem. However, in the last hundred years many such areas have been wholly or partially drained, and then settled, with consequential disruption to established transhumance patterns. For example, the Campo de Dalías on the south coast of Spain used to be a valuable winter grazing ground for flocks from the hills, until it was partially drained and used for intensive agriculture. ${ }^{33}$ Studies of transhumance need to be alert to evidence, whether archaeological or documentary, on environmental change.

\section{THE LOCATION/MOVEMENT OF ANIMALS}

The second factor relates to the extent of movement of the flocks. It seems to us that a tripartite typology is helpful here.

i. localised herding at a permanent settlement, i.e. stationary pastoralism, usually unspecialised in terms of its products (on which see 4 below) and practised alongside other forms of husbandry. In Italy this is known as stanziale (stalled) pastoralism, in which the flocks are herded on a daily basis on a radius of three to six kilometres round the village. ${ }^{34}$ In Greece on the Methana peninsula small flocks of 6-13 are kept by individual households as part of the local agrarian economy. ${ }^{35}$ This form of pastoralism is also common in parts of the Peloponnese, where it was (and to some extent still is) an important economic activity, with flock sizes sometimes in excess of $100 .^{36}$ Though this type of animal husbandry receives little attention in 
this paper, a fuller study would expand on our variables and make them applicable to pastoralism in general.

ii. a mobile economy within a restricted area. That is, the flocks might go up to summer pastures a day's walk or so from the permanent settlement. Examples of this would be the alpine pastures of Switzerland, which lie 700-1000 m above the valley floor; ${ }^{37}$ or the Madhares or summer pastures of the White Mountains of Crete, some $1200 \mathrm{~m}$ above the villages.

iii. long distance transhumant economy. That is, the seasonal migration of flocks over considerable distances. Examples of this category are the movements of the Sarakatsani and their flocks $75-100 \mathrm{~km},{ }^{38}$ the herding of animals up to $200 \mathrm{~km}$ between the Pindus and northern Thessaly, ${ }^{39}$ between the Abruzzi up to $200 \mathrm{~km}$ to Puglia and over $100 \mathrm{~km}$ to the plain near Rome, ${ }^{40} 700 \mathrm{~km}$ in the case of Castilian transhumance. ${ }^{41}$

A distinction is often drawn here between 'normal' transhumance (where the winter residence is in the lowlands and the mountains used simply as a summer resource, as in fig.1) and 'inverse' transhumance (in which as with the Vlachs the mountains were the basic home and the plain used as a winter resource, as in fig.2). ${ }^{42}$ There is also a distinction drawn within the category of 'normal' transhumance, depending on whether the whole village moves part way up the route towards the summer pastures, abandoning the winter village for part of the year. Such distinctions do not seem to us to be very helpful for understanding the scale and function of transhumance: for those it does not matter whether the basic flow of people and animals is up or down, though it may well be important for the issue of cultural integration (below, section 7).

Only types ii and iii, with restricted or long-distance movements, count as transhumance. Stationary and transhumant pastoralism can be practised simultaneously by the same culture, but if there is any transhumance there will be a predictable annual cycle of movement from one known location to another (see further below, section 7.). The route followed is also predictable, sometimes fixed by custom, sometimes regulated by the state. For example, in the Biferno valley of east central Italy wide drove roads ran diagonally across the valley, affording a route between lowland and upland pastures. Cultivation of them was prohibited by the state. ${ }^{43}$ 


\section{SCALE}

The prime determinant of the need for transhumance is scale: the larger the size of flock, the harder it is to provide year-round supplies of fodder in one place. Mediterranean pastoralists whose fixed base is in the lowlands have difficulties with summer fodder at low altitudes, while those whose main base is in the highlands have corresponding problems with winter fodder (as has been shown for NW Greece). ${ }^{44}$ This factor has changed only relatively recently with the possibility of bringing in feed, and indeed water, to permanent settlements. Before the development of modern modes of transport only small numbers of animals could remain in any given place year round (though of course transhumant flocks might coexist with stationary flocks during the locally fertile period, as in parts of the Peloponnese during the winter). Conversely, seasonal transhumance is not worth the effort and risks unless the scale and hence potential profits are larger. That is, stationary pastoralism will typically involve fewer animals than either restricted or long-distance transhumance.

Two variables greatly affect the possibility of engaging in large-scale pastoralism, involving restricted or long-distance transhumance. First, state organisation. States have a major impact on the practices of transhumance. ${ }^{45}$ This takes two forms. The social and political organisation of the state is a crucial context within which members of the community operated. In classical Athens, for example, it is likely that animal husbandry was a common element on the estates of wealthy citizens, alongside arable culture. This was market-oriented production, designed to increase the income of the wealthy to enable them to meet their high levels of competitive political expenditure. ${ }^{46}$

Secondly, states may themselves have an interest in pastoral activity, which they may be involved in promoting. Such intervention has a major effect on the level and extent of pastoral activity. For example, the small-scale states of Hellenistic Crete arranged for the passage of animals across their borders in a series of treaties. ${ }^{47}$ The states might profit from pastoralism via taxation, but they also served the interests of their citizens. A common problem is conflicts between shepherds and agriculturalists over the routes for transhumance: animals could stray off designated routes and damage crops, while farmers themselves tried to place those routes under 
cultivation. In Italy under Roman rule, rents for summer pastures were paid to the state, and in turn officials of the state might intervene to ensure the smooth transit of men and animals. Texts of the first century BC show that pasture taxes were collected in the normal manner (by the publicani), and inscriptions from the Abruzzi illustrate the continuity of state involvement between the second and the sixth century AD. ${ }^{48}$ Similarly, in Spain royal letters of privilege dating back to AD. 1273 permitted the noble sheep-farmers of northern Spain (organised in the Honourable Assembly of the Mesta) to send their flocks south for the winter, along designated roads (where a dozen royal tolls were levied). The passage of 2.5-3 million animals twice a year inevitably led to conflicts between shepherds and peasant farmers, especially in the south, but the state intervened consistently in favour of the Mesta, and thus helped pastoralism to be the most important aspect of the Spanish economy in the fifteenth and sixteenth centuries. ${ }^{49}$ Alternatively, the growth of state power, along with population growth and agricultural expansion, can inhibit or even terminate nomadic pastoralism. ${ }^{50}$ Sedentization of the formerly mobile population may be the outcome.

States may themselves not merely profit indirectly, from the levying of taxes (for transit rights, pasture rights or on markets), but may also be more closely involved in the organisation of pastoralism. The Linear B tablets from Pylos and Knossos of the later second millennium BC cast considerable light on the palatial organisation of pastoral production. The 'palaces', such as those at Pylos in the Peloponnese and Knossos on Crete, were large architectural complexes with substantial storage capacities; a bureaucracy recorded commodities (grain and animals) and personnel, within the territory of the palace. The Linear B tablets have produced excellent evidence for a large-scale, centrally regulated wool industry dependent on pastoralism which specialised in terms of production. Shepherds were given targets for numbers of animals and for amounts of wool by weight by the palace administration. The management of $80,000-100,000$ sheep in the central part of the island is implied by the Knossos tablets. The wool was processed into cloth, which ended up in the palace for further work if needed (e.g. fulling or added edges), and for storage and distribution. ${ }^{51}$ One difference, however, between Knossos and Pylos concerns the extent of palatial control. At Knossos the breeding of sheep was done largely 
outside the palatial sector, and extra lambs acquired by the palace by exchange, while at Pylos the palace was largely self-sufficient in the maintenance of its flocks. ${ }^{52}$

Second, markets. The increase of scale implied by the adoption of transhumance rather than simple stationary herding normally makes sense only if production was not simply for subsistence. That is, transhumance is typically dependent on the existence of markets for the exchange or sale of what was surplus to local needs. ${ }^{53}$ Such markets may take different forms. In cases of palatially organised pastoralism the palace was in some sense the primary 'market'. Palatial control was both bureaucratic and perhaps literal, if all wool or wool products physically went to the palace, for use there or subsequent exchange. In the medieval and modern world, it may be tempting to gloss over the importance of markets for the sale of pastoralist goods. A romantic fallacy on a par with the notion that transhumance is an unchanging aspect of the Mediterranean is the assumption that the transhumant shepherd is an isolated figure, remote and cut off from the wider world. In fact the opposite is true. Though individual shepherds may value their freedom from the outside world, their life makes economic sense only if there is access to a market for their goods. So for example Cretan cheeses were widely exported in the Venetian period to Alexandria, France and Italy. ${ }^{54}$ For example, a British traveller who visited Crete just after the Ottoman take-over, commented:

The cheese which is made here [in the White Mountains] is bought up by the Venetians and other Merchants, and transported to France, Italy, Zante etc. It

is the best cheese that is made in any of the Southern parts, and generally as good as our own Cheshire cheeses, being made as bigg. ${ }^{55}$

The quality of the product was sufficient for it to be competitive even in relatively distant markets where local cheeses would also have been available. The specific pattern of trade will have been determined by the nature of the occupying power: under Venetian rule trade looked west (that is the pattern which Randolph picked up), while under Turkish rule cheese was also exported to the north and east. But the general point remains that the seemingly remote and isolated parts of the island were tied in to a market economy. Indeed transhumance is worth undertaking only if a significant proportion of the product is destined for exchange or sale. The 
factor of states and palatial or urban markets helps to explain the development of transhumant pastoralism. Conversely, the weakness or absence of this factor can be used to date the development of the practice in the prehistoric period. ${ }^{56}$

\section{SPECIALISATION IN PRODUCTS}

Sheep and goats are flexible animals, which produce three quite different items: meat, milk (usually for cheese), and wool. While any given animal or herd may be used for all three products, as sometimes with stationary pastoralism, it is also possible to specialise in just one of the products. So wool may be the primary product, with the others used in a secondary capacity. In addition, manure may also have economic value (its presence on the pasture lands being used to reduce the level of rent payable). The three products can be combined in a variety of ways, but the initial use of sheep and goats was for meat, and use of their milk or wool occurred for the first time in the Old World in the third millennium BC, an important element of the 'secondary products revolution'. ${ }^{57}$ Specialisation in meat on any large scale is possible (in the pre-modern world) only if there is easy access to large urban or palatial markets.

Specialisation may be reached in two ways, either through breeding or through the management of the herd. The success of the Mesta was derived from the spread of the merino sheep in the fourteenth century, which was itself the product of crossbreeding between Spanish sheep and animals brought over from North Africa. These fine-wooled animals, quite different from the local sheep which did not transhume, produced wool of high quality for international markets. Management of the herd is employed to ensure maximum production of (for example) meat rather than milk. In fact, each product requires a different style of management and flock structure: for example, if milk for cheese is needed, the flock will consist of more ewes and fewer rams than if wool is to be the primary product. For example, eighteenth century Italian accounts of one noble family show how the flock was managed to maintain production of $50 \%$ wool, $40 \%$ meat and $10 \%$ cheese. But even specialised pastoralism retains flexibility: it is relatively easy to change the balance of production from, for example, wool to cheese within a short time. This kind of changr can be necessary as a response to crisis. After severe losses of 
$43 \%$ in the winter of 1726 the same Italian accounts show how the ratio of lambs to ewes was increased (from $15 \%$ to $57 \%$ ) to build up the flock again as quickly as possible, while still registering some level of annual profit. ${ }^{58}$

Specialisation is characteristic of large-scale transhumance. Indeed the greater the scale, the greater the degree of specialisation; it is worth increasing the risk entailed by specialisation only for the sake of a large market or a greater profit. So for example the Linear B tablets from Knossos show that the pastoral system controlled by the palace specialised in cloth manufacture. The shepherds managed flocks in such a way as to maximise wool production. They were given targets for numbers of animals and for amounts of wool by weight. The wool, in weighed amounts, was supplied to weavers, in various parts of Crete including Knossos, for them to make cloth of specified weights; once again, targets were set, in this case for textile production. ${ }^{59}$ This specialisation was a matter of choice, not of environmental determinism. As we have seen, Cretan transhumance in more recent centuries has been famous for cheese production; this remains true today, when Cretan cheese, not unlike that praised by Randolph in the seventeenth century, is prized throughout Greece. Some meat is sold, but the wool cannot compete for weaving with finer imported wool or with cheap synthetics, and at current prices can often not be sold even for felting or mattresses.

\section{LINKS WITH AGRICULTURE}

There used to be a romantic notion that transhumance was entirely distinct from, and often in opposition to, agriculture, but as Owen Lattimore has said, 'the only pure pastoralist is a poor pastoralist'. ${ }^{60}$ Nomadic pastoralists can be wholly dependent on their domestic herds for subsistence, but this is not a necessary feature of nomadic pastoralism and some nomadic pastoralists do engage in agriculture. ${ }^{61}$ Non-nomadic pastoral systems are closely tied in with agriculture; and greater specialisation and long-distance transhumance is possible only if some people are engaged in serious agriculture (the pastoralist cannot live by wool alone, or even cheese and chops). ${ }^{62}$ The nature of the links between transhumant pastoralism and agriculture depends on the distances involved, and who actually moves (men only, whether unmarried 
shepherds or heads of households, or whole families). The scheduling of labour for the two sets of activities complements each other at times, and at other times results in pressures and strains. $^{63}$ In Sphakia, the absence of men for long periods between May/June and October obviously affects the labour resources of the village, and results in two parallel production systems (pastoral and arable). Men might have been able to help with the harvesting of pulses (early May), but at least some of the agricultural work would have to be done by women. Grain is harvested in late May-June, though the lack of rain at this period means that it is a less pressured activity than in northern Europe. Grapes are picked for eating in August and for wine in late September, but they have not been a major crop in most of Sphakia. Once the men were down from the summer pastures in the Madhares, so long as they were not tending the animals on the coast, they could help with the sowing of grain, pulses and vetches, and the gathering of olives. ${ }^{64}$

Then there is the issue of manure. Sheep produce $500 \mathrm{~kg}$ of manure each year (or 10 times their own body weight), and this manure can be of considerable value as a fertiliser; ${ }^{65}$ the use of manure, derived partly from animals kept at the settlement, has received much attention from survey archaeologists. ${ }^{66}$ In early modern Italy the transhumance routes had royally regulated 'lay-bys', on agricultural land that was lying fallow that year. ${ }^{67}$ And the grazing in winter on arable land also formed part of a mutually beneficial system. In return for payment of royal taxes, the crown allocated winter grazing land to sheep-owners. The land was subject to a six-year rotation: two years of barley, one of wheat, two of grazing and one of complete repose. ${ }^{68}$ Even in cases where the ownership of land and animals is different, arable and pastoral can be complementary. ${ }^{69}$ In other cases the value of the manure was calculated into the level of rents charged on grazing land. That is, though conflicts often occur over the actual transit of animals, especially when the animals are not owned by the cultivators, one should not think of atavistic conflict between pastoralists and agriculturalists. There can be conflict and there are choices to be made between agriculture and pastoralism, but there can also be dovetailing of the two systems of exploitation of the landscape. 


\section{GENDER AND THE DIVISION OF LABOUR}

Though gender and the division of labour have become part of general archaeological discussions and some specific case studies, ${ }^{70}$ they have been omitted from most discussions of pastoralism. People often assume, usually implicitly, that the work of pastoralism includes only shepherding by adult males. We suggest here that such an assumption actively prevents a full understanding of pastoral societies, and how they change and develop over time. Pastoral societies, like others, may be strongly gendered, but it is analytically important to know what the women, as well as the men, are doing. We see two main variations on the theme of the division of labour by gender: 1. direct, where women and men are directly involved in animal husbandry and/or the production of specialised pastoral products (cloth, cheese, meat); and 2. indirect, where women are responsible for other economically important work, thus enabling men to focus on pastoralist activities; the work of both is necessary to maintain the total economy.

In this section we look first at twentieth century Sphakia, an example of the indirect model (Fig. 1), and second at the Vlachs, an example of direct female and male involvement in pastoralist work (Fig. 2). In both cases we take a diachronic view, in order to demonstrate the usefulness of gender as a variable when looking at changes in a particular pastoralist system. Next we will consider the impact of keeping gender in mind when studying the organisation of shepherding and textile production in the Late Bronze Age, using the Linear B texts as primary evidence. Finally, we look briefly at the age and gender of pastoralists.

\section{INDIRECT CONTRIBUTION OF WOMEN TO PASTORALISM: 20TH C. SPHAKIA}

We will begin with an example of the indirect contribution of women to pastoralism in twentieth century Sphakia, focusing mainly on the village of Anopoli. Anopoli is one of several non-nucleated villages in Sphakia, with several neighbourhoods, based on virilocal kin-groups; it is located at ca $600-800 \mathrm{~m}$, the 'middle' altitude mentioned above. Before the construction of car roads, men and boys old enough to walk that far took the flocks (sheep with a few goats) to the Madhares, or summer pastures, which at ca $1800 \mathrm{~m}$ constitute the 'up' altitude for this part of Sphakia. They went up to shepherds' huts (mitata) which again were based on (smaller) kin 
groups, in order to make cheese, graviera for export, often over long distances, and anthotyro, mainly then for local consumption because it spoils quickly. The men and boys left Anopoli when enough snow had melted to make the ascent possible, from late May at the earliest and more usually June, and came down for the winter when the snow started again, in late September or early October. They did not stay up for the whole time, but rather went up in rotation over the three or four month period.

It would be easy to assume that women did not go up with the men because they were somehow immobile, and needed to stay 'at home'. But in other parts of Sphakia (again until the construction of car roads), where all three altitudes were in regular use, women and children did move, from 'down' in a winter village, to a summer in the 'middle' altitude; it was only the 'up' altitude, with its summer pastures, to which they did not move. An example of a three-altitude area is nearby: Khora Sphakion, with its four neighbourhoods, 'down' at the coast; Kaloi Lakkoi, the 'middle' summer village; and the shepherds' huts still further 'up'. So despite the 'stay-at-home' ideology, women could move from one altitude to another; they just did not go up all the way to the summer pastures.

It would also be easy to assume that the women 'did nothing' (i.e. nothing of economic importance) while the men were up in the Madhares. Indeed it is true that the time in the summer pastures does coincide, roughly, with a period when there is relatively little agricultural work to do: in most cases, by the time that enough snow had melted for the ascent to be possible, the grain harvest was already over. But to take this view is to assume that women had no responsibility for agriculture, and it is this assumption that needs to be examined. Ideologically, women are not supposed to be farmers; in reality, however, women frequently did (and do) the agricultural tasks connected with grain, conceptualised as exclusively 'men's work'. Women also picked grapes in late August/September in Anopoli, when most men were still up in the Madhares, and collected olives in November, after the men were down from the mountains, when ideologically their help should not have been needed.

Given the usual close links between pastoralism and agriculture, it makes much more sense to assume that if the men are off with the sheep, the women play an important role in 
maintaining the agricultural momentum of the group in their absence. Who else could be responsible for the other 'labours' necessary to keep the economy functioning smoothly? Our first point, then, is that the activities of women in pastoralist societies must always be taken into account, because it is the integration of women's work and men's work that keeps the whole economic system going. ${ }^{71}$

Our second point here is that the work of women, even when not directly linked to the main product(s) of specialised pastoralism, is important to analyse. In the case of Anopoli, there are some interesting changes in the textile production which develop in parallel with changes in the pastoral system. The main product of pastoralism in Sphakia from at least the Turkish period is cheese, but wool from the sheep was traditionally spun, woven, and used for a variety of economically and culturally important textiles such as shepherds' cloaks, blankets and bedspreads, woollen cloth for clothing, all of which were part of a young woman's dowry. A woman did her weaving at home, often on a loom in the courtyard of her house. (Other tasks associated with textile production, such as spinning or gathering plants for dyeing, were done elsewhere, just as for agricultural work). ${ }^{72}$

Things have changed since roads were built and, more recently, since Greece joined what is now the European Union. Cheese is still the main product of pastoralism, but fewer and fewer sheep are taken up to the summer pastures, because EU subsidies pay for feed, which makes the journey unnecessary. Some cheese-making is done in a purpose-built factory in the central neighbourhood of Anopoli; some of the milk is now taken directly to Rethymno for cheese- and yoghurt-making there. The old system is being disrupted, both spatially (transhumance happens less and less; cheese production in the village is centralised in one neighbourhood), and organisationally (the work is less and less kin-based).

Textile production provides an interesting parallel. The sheep are still shorn, but the fleeces are discarded. Women still weave on their own looms, but in a purpose-built, EUfunded, weavery (iphandirio) near the central neighbourhood, using bought fibres (cotton and silk). The textiles are sold for money, often outside Sphakia, as well as being produced for dowry. In the case of Anopoli, textile production is now completely separated from pastoralism 
(discontinuity), though still done by women and still important for dowry (continuity). It is of particular interest that the changes in pastoralism are paralleled by the changes in textile production, even though the two were never as closely linked as they would be in a textilefocused system. Changes such as emigration, road-building, and EU membership have combined to produce forms of cheese and cloth production which are more separate than ever, but still structurally similar: more dependent on subsidies and less dependent on kin-based labour; increasingly done in a central location, and decreasingly done 'at home' (whether in a house or a shepherd's hut). Leaving gender out of the economic equation would have meant leaving out this important set of structural observations.

\section{DIRECT CONTRIBUTION OF WOMEN TO PASTORALISM: 20TH C. VLACHS}

The division of labour by gender is particularly important in specialised pastoralism-who turns wool into cloth, milk into cheese, butchered carcasses into food, hides into leather? Wace and Thompson's account of Vlachs, mostly en route to, and in, the village of Samarina, at a time when transhumance was already in decline, makes clear that though cheese and meat were sold as well as consumed locally, wool for textiles was 'the most important trade of the village', and that wool-working was done almost exclusively by women. Wool was bought after shearing in the spring, made into cloth and carpets in the summer, and the textiles sold at fairs, chiefly Konitsa in September. Most houses in Samarina had a room for wool-working on the ground floor, with carding equipment, a spinning-wheel, a skein-winder, and a loom. The importance of wool was ritualised in Vlach marriage rituals: when the bride arrived at the groom's house, her mother-in-law welcomed her in a ceremony including a handful of carded wool. Wool and its transformation by women into usable and saleable items thus constituted the backbone of the Vlach economy. ${ }^{73}$ To exclude wool-working and women's part in it, by limiting the definition of pastoralism to shepherding, would have meant an incomplete analysis of Vlach transhumance in this period.

By the time of Sivignon's research in the 1960s, transhumance was no longer mainstream, and many Vlach families were basically sedentary, making only short, more or less 
touristic visits to summer villages like Samarina. Nonetheless both sheep and textiles are still important. Sivignon's summary of the relationship between the two is, however, revealing:

Les Valaques sont aussi connus pour leur habileté à travailler la laine que pour leurs activités proprement pastorales. Les deux industries sont liées (emphasis ours). ${ }^{74}$

To Sivignon, wool-working is not, strictly speaking, a pastoral activity; and yet, for those Vlachs still engaged in transhumance, wool-working continues to be the crucial economic aspect of pastoralism, even though the type of textiles produced was shifting away from the traditional cloth (scouti) and carpets of earlier years, made for local Balkan consumption, to flokati rugs for the tourist market. Sivignon does include a useful analysis of the continuity of economic arrangements providing credit for the purchase of wool: in Wace and Thompson's time, credit was ubiquitous and informal, with all debts being settled at the September fair in Konitsa; in 1957, a co-operative was formed to regulate credit. ${ }^{75}$

Chang and Tourtellotte worked in this same area in the 1980s, with the stated goal of finding material correlates of transhumant pastoralism. Although their study includes much useful discussion of theory, they do not discuss definitions of pastoralism, and it only gradually becomes clear that their definition is the minimalist shepherding version. There is no mention of women and their possible contribution to the functioning of the overall economic system, nor, therefore, of any possible material correlates of wool-working (wool-working rooms in houses, wool-working equipment, beetling mill). As a result it is not possible to use their valuable work for an update on gender and division of labour among transhumant Vlachs since Greece entered the European Union. ${ }^{76}$ Ironically, it is Wace and Thompson's book, the earliest study of these three, that provides the most information about gender and the division of labour.

\section{GENDER AND PASTORALISM IN THE LATE BRONZE AGE LINEAR B} TABLETS

We turn now to our final example, that of pastoralism, possibly transhumant in part, in the Aegean Bronze Age. The Linear B tablets show that the pastoralist system regulated by the palatial centres was specialised to wool, like that of the Vlachs discussed above. The tablets 
provide evidence for the two major stages involved, shepherding and textile production, and they show that the division of labour was very clearly gendered: men raised sheep for wool, and women were almost entirely responsible for turning the wool into cloth of various kinds. ${ }^{77}$

Elsewhere Nixon has questioned the rigid separation of male shepherds and predominantly female wool-workers in most scholarly discussions. Ethnographic work on pastoralist societies and textile production suggests that one common way of integrating the labours of producing wool and making cloth is to have households consisting of at least one male shepherd and one female weaver, and any children they might have. In the case of the Aegean Bronze Age, such households could be located outside palace centres (as well as inside them) while still under palace control. And indeed there are some places mentioned in the tablets which have both shepherds and cloth-workers (da-wo and pa-i-to on the Knossos tablets; pu-ro ra-u-ra-ti-jo in the Pylos archive). Nixon has argued that the ta-ra-si-ja system is just what one would expect of an integrated shepherd-weaver system, with the raw materials and finished products carefully measured at every stage so that shepherds and weavers could not engage in household 'embezzlement' of sheep, wool, or cloth. Looking at gender within the pastoralist system supervised by the palaces suggests that the women involved in textile production could occupy very different social positions. The female weavers in group 9 at Pylos were not local -they are described as ki-ni-di-ja, 'from Knidos', and their status may have approached slavery; at the other end of the scale, we know of a royal female cloth-finisher at Thebes. ${ }^{78}$ Outside the palatial system -- for the palaces probably did not control all aspects of the economy -- the work of pastoralism will also have been gendered, though not necessarily on exactly the same lines. ${ }^{79}$

Thus within the Bronze Age Aegean it is possible, indeed necessary, to talk of different versions of pastoralism, geared to different textile productions. Once again, a gendered discussion of pastoralism results in a more nuanced discussion of the evidence, and in the generation of new questions. Because women and cloth are frequently associated in ancient and modern economies, it is crucial for scholars to realise that each specialised pastoral society will have its own version of textile production, and that we cannot predict precisely how each production system will be organised, and who did what, in terms of gender. The following 
example should serve as a final warning about jumping to gendered conclusions: in central Asia, carding and spinning are done by all members of the community, men and women, old and young. ${ }^{80}$

\section{THE AGE AND GENDER OF PASTORALISTS}

The age of individual pastoralists has not so far been considered here. On the whole, in the cases that we have studied, women do not usually work directly with animals. And yet in some instances it is clear that females actually do look after sheep and goats, as songs like 'Il était une bergère' and 'Voskopoula' remind us. We ourselves have occasionally observed a woman milking sheep in Anopoli. Why are there not more examples? The shepherdess of the song 'Voskopoula' is a girl; and the woman whom we saw in Sphakia was then in her early fifties. In other words, one was too young, and the other too old, to have children. There may be a serious constraint on the participation by women of reproductive age in pastoral work involving direct contact with animals, in the form of zoonoses such as toxoplasmosis. These are diseases which can be transferred from animals to humans, with similar effects. Ewes infected with toxoplasmosis when pregnant will abort or produce lambs that die soon after birth. Pregnant women who come into direct contact with infected ewes, especially at lambing, may also abort, or give birth to children with congenital infections and defects. ${ }^{81}$ It may well be the case, then, that women of reproductive age originally began to avoid direct contact with sheep and goats for zoonotic reasons. Thus pre-pubertal girls and menopausal women would have been the only females who could safely come into direct contact with pastoral animals. Age and sex thus need to be taken into account together, because pre- and post-reproductive women could be the only females who can tend animals kept close to home, in societies where men do long-distance transhumance with large flocks, as well as in societies where there is no transhumance.

In this section, our major point has been that the activities of women in pastoralist societies must always be taken into account, because it is the integration of everyone's work that keeps the 
whole economic system going. Thus in order to make accurate, comparative assessments of pastoral systems, transhumant or otherwise, we must bear in mind that pastoralists, like farmers, come in both sexes and several ages.

All three of the examples discussed here show the importance of a realistic definition of the work involved in pastoralism. The proper functioning of most pastoralist systems depends on the work of women as well as men, either directly, in the two cases of pastoralism specialised to wool (Vlachs and Linear B), or indirectly (Sphakia), when agricultural and other work is continued by women while men concentrate on pastoralism. ${ }^{82}$ For many different reasons it is regrettable that most studies of pastoralism have concentrated on what the men do, and failed to address the question of the location of female labour within the overall system; in some ways the division of labour is not always a good phrase. 'Integration' of labour may be better, not least because it allows for the possibility of the disintegration of labour over time as systems change and in some cases actually unravel. Thus gender is part of the archaeology, history and anthropology of pastoralism, and is fundamental to the type of comparison proposed in this article.

\section{CULTURAL INTEGRATION}

Cultural integration is the last of the seven factors discussed here, for making synchronic and diachronic comparisons between different pastoral systems. Here we explore the following cultural categories: seasonal calendars, religion, metaphor and symbol (both iconographic and written), consumption, the status of pastoralism, and attitude to pastoral landscape. While other articles have touched on the importance of such aspects, ${ }^{83}$ they have not grouped them as 'cultural' and therefore have not made explicit use of them as tools for comparison. We hope to demonstrate how useful cultural integration can be for assessing the role(s) of pastoralism in a particular time and place. The cultural categories used here are relevant to all periods, and potentially detectable from most if not all kinds of evidence.

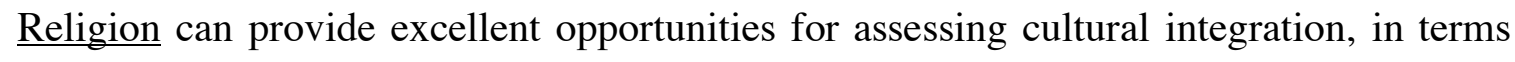


of deities, rituals, and sanctuaries. The contrast between classical Greek religion and Christianity is most informative. The Greek pantheon includes Hermes, an anthropomorphic Olympian god sometimes associated with cattle, and goat-footed Pan, linked with ovicaprids. Christ is known both as the Lamb of God and as the Good Shepherd. Hermes surely had higher status than Pan, at least when he was not thought of in relation to animals.

The location of sanctuaries is also of interest. Minoan peak sanctuaries may have been placed with reference to pastoral activities; recent work at Atsipadhes in central Crete suggests, through analysis of the animal figurines, that cattle as well as ovicaprids could be important in worship. $^{84}$ In part of Arcadia, on the Greek mainland, Hermes was seen as the god of shepherds, and had sanctuaries on mountain peaks (as well as in urban settings); ${ }^{85}$ Pan was honoured mainly in caves, and was again associated with shepherds. ${ }^{86}$

Dedications at the sanctuary of Hermes and Aphrodite at Kato Syme, SE Crete, in the Geometric/ Archaic period included one or two bronze plaques depicting a man, possibly a shepherd, bringing a ram for sacrifice (and many others with a man, presumably a hunter, bringing an ibex). ${ }^{87}$ To the best of our knowledge, no collection of ovicaprid dedications can match the unique fourth-third century BC bull shrine found at Tsiskiana in west Crete. ${ }^{88}$

Modern Greek outlying chapels (xoklisia) are occasionally built in locations explained only by pastoralism but are not otherwise distinguished architecturally or by votives from other churches or xoklisia. An example is the xoklisi of Agio Pnevma (2260 masl), built on one of the ridges separating the $\mathrm{N}$ and $\mathrm{S}$ slopes of the White Mountains in Sphakia, in an area used only by transhumant pastoralists. The church marks the boundary between two administrative districts, Sphakia and Apokoronas (and within Apokoronas, the boundary where three koinotites converge). ${ }^{89}$

Some of the cultural categories to be discussed here overlap, both with each other and also with the preceding six factors. Calendar is a case in point: here we are expanding the familiar faunal view of seasonality and kill/cull dates, and moving beyond the kind of scheduling associated with agro-pastoralism, because the structure of time and the placement of events within it are themselves cultural artefacts. For example, in classical Attica a peak period 
for ovicaprid sacrifices was just before the migration of the flocks to scarcer summer pastures. ${ }^{90}$

The timing of major (human) life-cycle events among the Vlachs in the early twentieth century provides a good example of a culturally integrated calendar. Even after pastoralism ceased to be the economic mainspring of the group, engagements and weddings were celebrated in the summer when people had returned to their 'real', upland village. ${ }^{91}$ Similarly, St George's day (23 April) and St Demetrios' day (26 October) took on a special significance among transhumant groups in some parts of Greece because they coincided with the annual movements of the flocks. ${ }^{92}$ In other words, an important pastoral event enhanced the meaning of a day in the religious calendar.

Symbol and metaphor, whether verbal or visual, can be useful indices of cultural integration but require careful interpretation. A case in point is the phrase "shepherd of the people' used of kings in Homeric epic, which as Murray states is only a metaphor for rulers, not the metaphor, and was probably borrowed from Near Eastern sources. ${ }^{93}$ Moreover, Greek rulers are never as far as we know actually portrayed as shepherds. Nor are Greek citizens routinely compared, either verbally or visually, to sheep, whose docility is more useful in a monarchy or theocracy. ${ }^{94}$

The Christian view of shepherds and flocks is very different and a positive one, springing from the Near Eastern tradition. The Lord can be a Shepherd (Ps. 23); Christ can be both shepherd (John 10) and lamb of God as already mentioned, in art as in texts. Representatives of Christ can also be (good) shepherds, whether as Christian rulers or as bishops with their crosiers. Members of the Christian community constitute Christ's flock--and they are definitely sheep (John 10) rather than goats (Matth. 25: 32-395). Pastoral imagery does not, however, show that pastoralism is still important in the economy of a society. After all, even in the industrial west Christ is represented as a shepherd and bishops carry crosiers.

Previous discussions of pastoralism have been long on production--numbers and species of animals, kill/cull schedules, management of flocks, specialisation, etc.--but short on consumption--the actual use of pastoral products, which is after all the point of production. Patterns of consumption are now increasingly of interest to archaeologists and anthropologists as 
well as to economists, planners, and advertising companies. ${ }^{96}$ Here we will look briefly at some of the topics directly relevant to the analysis of pastoral systems, using the products themselves as headings, in the hope that consumption will be put firmly on the agenda of future pastoral studies.

Meat is in many ways the most consistently important pastoral product; like others, it satisfies more than one type of hunger. The Linear B documents from Thebes, Pylos and Knossos tell us of animals being supplied for major ceremonial banquets; the exact nature of the occasion(s) is not known, but the use of meat to enhance the status of the menu and its conspicuous consumers seems clear. ${ }^{97}$ In the Iron Age, as already mentioned, meat animals served the double purpose of divine sacrifice and communal feasting, ovicaprids as well as cattle. These activities are faunally verifiable from sanctuary deposits such as those at Kommos. ${ }^{98}$

For obvious symbolic reasons, lamb is important for Christian celebrations, though (and this is important) it is not prescribed in the New Testament as the essential item for, say, Easter. Even so, in Greece lamb at Easter, in many ways is Easter--both the roast lamb and the special soup (mageiritsa) that precedes it. The work of Gavrielides in a Peloponnesian village shows that traditional Greek meat consumption, like ancient consumption, was carefully patterned, with strong ritual links. ${ }^{99}$ Goat is also consumed but does not have the overwhelmingly positive symbolic significance of lamb. Herzfeld's study of Cretan shepherds in the Rethymnon area reveals that consumption can take surprising forms: some sheep thefts end abruptly in the consumption of secretly cooked lamb; others involve 'stealing to make friends', where the temporary absence of animals from an older man's flock represents an ephemeral consumption ending with the return of the sheep and the beginning of a new relationship between 'mentor' and thief. ${ }^{100}$ In Sphakia, as elsewhere in Greece, the ritual meals at weddings and saint's day celebrations include two meat courses, boiled meat with pilafi, and roast meat with potatoes, in an interesting combination of local meat and originally foreign starches.

In classical antiquity and in traditional modern Greece, the consumption of meat is largely public and communal with positive links to religious festivals. By contrast, the ancient 
view of transhumant pastoralists as 'eaters of flesh, drinkers of milk' (with a strong suspicion that the flesh was raw) shows that marginal groups were negatively marked, indeed tainted by the mainstream community's view of their particular consumption pattern. ${ }^{101}$ We will return later to milk.

It is easy nowadays to underestimate the crucial economic importance of textiles, despite the existence of haute couture as a form of conspicuous consumption. Here we will look briefly at wool and the textiles made from it, including cloth and sometimes felt. Wool in Sherratt's schema is a secondary product, ${ }^{102}$ and yet items made of wool should be seen as primary in one sense: meat by definition does not last; textiles, by comparison, are consumer durables, and therefore generate different patterns of consumption, conspicuous or otherwise. Many Bronze Age frescoes depict people wearing brightly coloured cloth, in patterns which Barber has shown to be weavable. ${ }^{103}$ Textiles from Knossos, along with perfumed oil from Pylos, are the only two commodities ever described in surviving Linear B documents as ke-se-nu-wi-ja, /xenwia/, 'foreign' or 'for import'. ${ }^{104}$ It is likely, then, that the weaving and display of high-status Minoan and Mycenaean textiles was as regulated as the consumption of meat (cf. Gavrielides cited above). In the Iron Age, patterned wool cloth is known to have had important social significance, whether as garments, bedclothes, or shrouds; high-status cloth was woven by (among others) high-status women. ${ }^{105}$

In traditional modern Greece, woollen items constituted a substantial part of the movable items in a woman's dowry: work wear, including shepherds' cloaks and backpacks, but also items for household use and display (blankets and bedspreads; hand-towels (petsetes). ${ }^{106}$

To conclude with milk: in the Mediterranean milk was traditionally not consumed immediately, but turned into something else--curds, yoghurt, or cheese, in ascending order of durability. This was not just because of the lack of refrigeration, but also because of lactose intolerance. ${ }^{107}$ Cheese is rarely mentioned in Linear B, perhaps not surprisingly, as large-scale pastoralism in the Bronze Age concentrated on wool. The later prejudice against 'eaters of flesh, drinkers of milk', has already been mentioned.

The view from societies where pastoralism had a higher status is of course different: 'a 
land of milk and honey', a phrase occurring many times in the Old Testament (see e.g. Ex. 3.8) is scarcely pejorative as it always describes the Promised Land. And the menu for communal feasts in Sphakia, such as baptisms, always includes a slice of the local graviera, with local thyme honey poured over it as a first course.

In discussing the status of pastoralists, we may usefully recall Murray's point about the link between the ancient Near East, and positive views of kings as shepherds or herdsmen of their people. ${ }^{108}$ In such societies it is possible that pastoralism itself has a more positive evaluation than in other societies. However, it is perfectly possible for a paradoxical contrast to exist between the high status of pastoral products, such as meat, and the low status of producers, as in contemporary Greece, where lamb continues to be prized, but shepherds are sometimes viewed as marginalised necessities. Similarly, graviera from Sphakia is known as the best, but the shepherds who make it are seen as backward and marginal (i.e. they are put in the same category as, say, hillbillies).

In any case, in societies with a negative view of pastoralism, shepherding will tend to be less visible as few people will voluntarily identify themselves as pastoralists. Instead they may opt to present themselves as agro-pastoralists, farmers who perhaps do a little shepherding on the side. Under such negative circumstances, transhumant pastoralists will be all the more conspicuous, and thus negatively regarded, because their very mobility makes them suspect. A related contemporary case will provide an example of how mobility can be smoothed away. In Canada and the U.S. 'trailers', irrevocably linked with culturally inappropriate shifting and shiftlessness, were renamed first 'mobile homes', and then 'MINI-homes', and the people who live in them categorised as 'trailer trash'. It is acceptable for a house to be small, but not for it to be a movable unit in a trailer or caravan park, still less in the U.K. a house for 'travellers'. ${ }^{109}$ Self-perceptions of difference are as important for pastoralists as for 'travellers': pride in being a sturdy outsider is one of the things that defines and sustains the pastoralists both of Sphakia and of the Pindus. ${ }^{110}$

Or contrast, once again, the examples, first of Oidipous cast out of an acceptably civilised polis into the wild marginal world of transhumant shepherds (one must have these 
people if only for narrative purposes?!), and second of St Luke's shepherds abiding in the fields, who were as Murray puts it, 'a primary structural element in the story [of Christ's nativity] and the Holy Family ... is secondary' (Luke 2.8-20). ${ }^{11}$

And now for attitudes to pastoral landscape. Attitudes to landscape are important and interesting in themselves; they are also reflected and discussed in texts, and can be deducible from archaeological evidence. In Greece, as well as in other parts of the Mediterranean, pastoralism is associated primarily with mountains, and there is frequently a dichotomy between (pastoral) mountains and (urbanised) plains.

Two Greek texts separated by nearly a millennium reveal a major change in ancient Greek attitudes to pastoral landscape. The first is Hesiod's eighth century BC Theogony, in which the poet says that the Muses taught him their song by breathing a divine voice into him on the highest slopes of Mt Helikon, while he was shepherding his lambs (Theog. 22-35). The song that Hesiod learnt from the Muses was no less than the Begetting of the Gods, in epic metre. The useful slopes of mountains like Helikon provided both pasturage and the opportunity to receive divine wisdom or inspiration, in the Near Eastern tradition, to the plains below. ${ }^{112}$

But Longus, writing in the late second/early third century $\mathrm{AD}$, narrates the story of Daphnis and Chloe in a prose poem called 'shepherd things' (poimeniká). Longus says that he himself saw this most beautiful spectacle in a grove of the Nymphs, while hunting (Daphnis and Chloe Proem 1). Pastoralism has become something done by other people in groves associated with lesser divine beings, with whom contact is not particularly important. During the short millennium separating Hesiod from Longus, the pastoral slopes of reality have long since become 'outside' and dangerous, while the pastoral plains of poetry have become increasingly cute, manicured, and unreal. This attitude to real pastoral landscapes--the arid upland slopes left over from lower arable terraces and plains--is of course closely related to the status of pastoralists, already discussed above. The only positive value of real pastoral landscape is its narratological usefulness in myths such as the story of Oedipus' rescue by shepherds on the slopes of Kithairon. ${ }^{113}$

There has been a similar change in attitudes to pastoral landscape in Greece during the 
last 300 years or so, from the traditional culture of the Ottoman period to the rather different outlook of the 1980s when the modern Greek state began to feel the effect of membership in the EU.

The culture of modern Greece is obviously Christian, so positive images of the Good Shepherd (from the New Testament but also by implication the Old) have been re-activated, in some cases very precisely: Sphakia, as we have seen, is literally and ritually a land of milk and honey. In terms of motion, much of traditional modern Greek life was a mixture of ascent to summer pastures and descent to winter settlements; both were good. The highest pastures, often in truly mountainous areas, tended to be seen as places of freedom -- from Venetians, Turks, and pettifogging bureaucrats of all kinds who tended to live a life of comfort, not to say luxury, in the plains where all of the major cities of Crete are located. ${ }^{114}$ In many ways the view of pastoral life as one of unfettered mobility and purposeful ranging over the landscape in order to ensure autarky is the key to definitions of identity for people living in places like Sphakia.

Since the 1950s, there have been major changes such as the accelerated migration from villages, and the entry of Greece into what is now the European Union. Pastoral landscape is still useful, but marginal, and differently organised. Changes in fencing practices reflect and symbolise the major shifts in use and perception of the landscape. Once, for example in Sphakia, walls of local stone were built to keep animals out of planted fields and gardens of vegetables; sheep and goats, moved constantly by shepherds to make use of all possible grazing areas. Now expensive, non-local metal fencing has been put up to keep the animals in. They move relatively little because they eat feed bought with EU money that has also paid for the new fences. The change from stone 'exclosures' to metal enclosures is materially clear, and reflects very precisely the shift from heroic, independent self-sufficiency to the prosaic constraints of EU subsidies and regulations that fence in the shepherds as much as their sheep.

\section{CONCLUSIONS}

Throughout this article we have cited evidence from various studies of transhumance in the 
Mediterranean. We have relied most heavily, however, on the two comparative charts (Figs. 1 and 2), in order to show how our seven variables interrelate, and to demonstrate the importance of 'post-processual' factors such as gender and cultural integration, as well as more traditional categories like scale and specialisation. Some comparative points have already been made above. In concluding the article, we want to add some more general comparative points relating to the two areas.

First, transhumant systems are not static but dynamic. In Sphakia, where we suspect that pastoralism, sometimes transhumant, has been important over a period of millennia, there may also have been a change in specialisation, from wool in the Bronze and possibly Iron Ages, to cheese in the (V)T period and the twentieth century (definitely). We can suggest that there was a switch in dominant pastoral products, even though we cannot yet explain it.

Second, for at least the last few hundred years, Sphakia has had a predominantly transhumant system of pastoralism, associated with agriculture. With the introduction of EU subsidies for feed, pastoralism is becoming a more stationary system, and agriculture has decreased because local self-sufficiency is no longer a necessity. The change in fencing practices discussed above in section VII shows, in material terms, the effects of this double change, away from the traditional combination of transhumance plus cultivation, timed to make the most of Sphakia's altitudinous terrain. In this case, we were able to explain the change from local stone exclosures to foreign metal enclosures by direct observation. Had we been working from purely archaeological observation, we would still have been able to explain a change in local practice in terms of some form of external influence or intervention.

Finally, there is a close, but complicated relationship between Mediterranean transhumant pastoralism involving sheep and goats on the one hand, and women and textiles on the other. Women are often, though not necessarily, linked with textiles, whether or not pastoralism, transhumant or otherwise, plays an important role in a given society. In an ovicaprid transhumant system, women and textile production may be strongly associated, and will have marked economic importance in two cases: if the system specialises in wool, in which case women's production of cloth for states or markets can be crucial; and/or if the society is 
basically self-sufficient, when women may be more or less totally responsible for domestic cloth production. The economic status of women can co-vary with the recognition of the economic status of textile production, whether for large-scale or domestic production. During the twentieth century there have been major changes in textile production, some of which have material correlates. In contemporary Anopoli, weaving can be seen as a transferable skill-transferable from the old VT days of autarkic home-based wool production, to the EU-funded weaving-place (iphandirio) in the centre of the village, where women weave cotton and silk cloth for cash, as part of a co-operative. Old woollens are still culturally integrated, in that they are carefully kept for daughters' dowries, and the dowries still include a high proportion of textiles. But because modern textile production no longer involves wool, weaving is now completely separate from any form of pastoralism.

As for the Pindus, the three studies considered here do not give quite enough attention to the different loci of activity. Long-distance transhumance in the Pindus requires three loci, at two different altitudes: 'down', for winter, 'up', for summer, and 'out', at the summer encampments around the summer villages. From an archaeological point of view, only the last locus shows unmistakable signs of long-distance transhumance (as Chang and Tourtellotte imply, but do not quite say explicitly). ${ }^{115}$

Generally speaking, the fullest of these three accounts of the Vlachs is the oldest, that of Wace and Thompson (who alone thought of learning Vlach as an integral part of their work). Sivignon does not spend much time on material culture; Chang and Tourtellotte, otherwise meticulous, omit any discussion of language (Vlach or Greek), or of marriage customs, the work of women in the contemporary pastoral/agricultural system, or even the numbers involved in transhumance. These entirely avoidable differences in basic data collection make it harder than it might have been to make a detailed diachronic study of changes in transhumant pastoralism in this region over the last century. It is interesting that the omissions noted here are in part relevant to the very 'post-processual' factors that archaeologists are now beginning to find crucial for the investigation of material culture.

Consider, then, the whole question of ethnicity and assimilation. All three scholarly 
projects focused on the Vlachs precisely because they were different -- long-distance transhumance in this case being closely linked with language and culture. Early this century Wace and Thompson described the ideal landscape of the Vlachs: mountains covered in grassy pasture; forests of oak, pine and beech; abundant, cold water; in short the antithesis of the ideal Greek setting of the time, which was urban. ${ }^{116}$ This is the landscape of the Vlach 'up', in the summer villages like Samarina, where the most important cultural activities of the year took place, including many outdoor activities (dancing, athletic competitions). Here the women did the wool-working, whose obvious economic importance to the whole community was certainly connected with the 'high status' of Vlach women noted by Wace and Thompson. ${ }^{117}$ By the time of Sivignon, a significant proportion of these Vlachs were more or less stationary, living not in the ideal landscape of the Pindus, but down on the plains. Along with the demise of formal instruction in Vlach came other changes, e.g. the gradual introduction of dowry. It ought still to be possible for thoughtful and conscientious researchers to situate contemporary Vlach men and women in a context of considerable cultural and economic transformation, and to document any changes in material culture that may accompany the shift from a separate transhumant Vlach identity to a more stationary Greek one. Thus the single most important observation to make about the Pindus chart is that even if modern researchers are not always directly interested in 'post-processual' issues, they should still make some effort to record information about them, not only for completeness, but also because such data can help to explain material patterns made visible through ethnoarchaeology.

In conclusion, we hope to have shown the value, indeed the necessity of comparison in the study of transhumance. On a personal level we can testify to the usefulness of comparative charts. Having first constructed one for Sphakia in 1993, we then had to account for discrepancies and were then able to answer a number of questions that had not previously been sharply posed. That is, such charts can be used to suggest further avenues of investigation. The problems of using the three Pindus studies would have been lessened if the authors had been thinking in comparative terms, and asking the sort of questions that were and are possible. The value, and even necessity, of using all the variables is clear: for example, zoo- 
archaeological/faunal work is crucial as an index of slaughter-times, which provides evidence for calendrical cycles and ritual practices; and ethnoarchaeological work, while usefully studying material correlates of contemporary practices can also helpfully record, for example, marriage customs.

Thinking comparatively is particularly fruitful in relation to one stable, or relatively stable, geographical setting. It is different from comparing transhumance in (say) North Africa, the Negev, and Spain, where the range of variables is in danger of being uncontrollable. Focusing on the same, though not necessarily constant, environment allows greater understanding of the changes in the other variables. Like the investigator of the evolution of animal or plant species, those interested in pastoralism need to think both about the variables affecting it, and about how they interact in particular contexts. We hope to have shown how focusing on a set of factors, including gender and cultural integration, can advance the study of pastoralism by ensuring a high degree of 'enforced consistency' in diachronic and comparative analysis. 
Fig. 1: Comparative Table for Transhumance in Sphakia, Crete, SW Greece

\begin{tabular}{|c|c|c|c|c|}
\hline & PREHISTORIC & $\begin{array}{l}\text { GRAECO- } \\
\text { ROMAN }\end{array}$ & $\begin{array}{l}\text { VENETIAN- } \\
\text { TURKISH } \\
\end{array}$ & 20TH C. \\
\hline 1 Environment & $\begin{array}{l}\text { changes at end of } \\
\text { Early Bronze Age. }\end{array}$ & no change. & Little Ice Age. & $\begin{array}{l}\text { same as Graeco- } \\
\text { Roman. }\end{array}$ \\
\hline $\begin{array}{l}2 \text { Location/ } \\
\text { movement }\end{array}$ & $\begin{array}{l}\text { up to Madhares from } \\
\text { Anopoli or Theriso. }\end{array}$ & $\begin{array}{l}\text { ii. Anopoli or } \\
\text { Theriso. }\end{array}$ & $\begin{array}{l}\text { ii. Anopoli (and } \\
\text { Theriso). }\end{array}$ & $\begin{array}{l}\text { i. no movement, } \\
\text { cheese produced in } \\
\text { Anopoli, and milk } \\
\text { sent to Rethymnon; ii. } \\
\text { Anopoli-Madhares } \\
\text { (but few). }\end{array}$ \\
\hline 3 Scale & $\begin{array}{l}\text { if transhumance, } \\
\text { then beyond } \\
\text { subsistence. palaces } \\
\text { regulated wool } \\
\text { industry, but was } \\
\text { Sphakia part of the } \\
\text { system? }\end{array}$ & $\begin{array}{l}\text { same? } \\
\text { market-driven; } \\
\text { some state } \\
\text { intervention in } \\
\text { Hellenistic period? }\end{array}$ & $\begin{array}{l}\text { beyond subsistence; } \\
\text { cheese sold overseas, } \\
\text { no V or T } \\
\text { intervention. }\end{array}$ & $\begin{array}{l}\text { i. EU subsidies for } \\
\text { feed, sheep sheds } \\
\text { (hypostega) and } \\
\text { cisterns; i. and ii. } \\
\text { market for cheese (no } \\
\text { Greek gov. } \\
\text { promotion). }\end{array}$ \\
\hline 4 Specialisation & $\begin{array}{l}\text { ?wool (cf. Linear B } \\
\text { tablets) }\end{array}$ & not known & $\begin{array}{l}\text { milk for cheese, } \\
\text { meat. Only local? } \\
\text { wool and textiles }\end{array}$ & $\begin{array}{l}\text { milk for cheese, meat } \\
\text { (local and tourists), } \\
\text { wool discarded after } \\
\text { shearing }\end{array}$ \\
\hline $\begin{array}{l}5 \text { Links with } \\
\text { agriculture }\end{array}$ & $\begin{array}{l}\text { if transhumance, } \\
\text { then could be like } \\
\text { early modern }\end{array}$ & same?? & $\begin{array}{l}\text { i. stone fences for } \\
\text { crops; ii. period in } \\
\text { Madhares coincides } \\
\text { with period of least } \\
\text { activity in Anopoli, }\end{array}$ & $\begin{array}{l}\text { i. same as for (B)VT; } \\
\text { ii. many terraces no } \\
\text { longer cultivated; wire } \\
\text { fences for animals. }\end{array}$ \\
\hline
\end{tabular}




\begin{tabular}{|c|c|c|c|c|}
\hline & & & except grape harvest. & \\
\hline $\begin{array}{l}6 \text { Gender and } \\
\text { division of labour }\end{array}$ & $\begin{array}{l}\text { if Sphakia like } \\
\text { palatial Crete, men = } \\
\text { shepherds, women } \\
\text { spin and weave }\end{array}$ & $\begin{array}{l}\text { if Sphakia like rest } \\
\text { of ancient Greece, } \\
\text { men = shepherds; if } \\
\text { wool, presumably } \\
\text { women spun and } \\
\text { wove it. }\end{array}$ & $\begin{array}{l}\text { men went up; women } \\
\text { stayed down with } \\
\text { children; women } \\
\text { spun and wove at } \\
\text { home }\end{array}$ & $\begin{array}{l}\text { i. women help men } \\
\text { with milking done } \\
\text { locally, within } \\
\text { families; some women } \\
\text { weave at iphandirio; } \\
\text { ii. men go up with } \\
\text { sheep; women stay } \\
\text { down and see to all } \\
\text { else. }\end{array}$ \\
\hline $\begin{array}{l}7 \text { Cultural } \\
\text { integration }\end{array}$ & & $\begin{array}{l}\text { elsewhere on Crete: } \\
\text { loom like plough } \\
\text { could not be } \\
\text { mortgaged; } \\
\text { shepherd votives }\end{array}$ & $\begin{array}{l}\text { new woollens crucial } \\
\text { in dowry, same as } \\
\text { 20th c?; Christianity } \\
\text { and good shepherd; } \\
\text { lamb consumption } \\
\text { like 20th c; Agio } \\
\text { Pnevma on line } \\
\text { between Anopoli and } \\
\text { Theriso }\end{array}$ & $\begin{array}{l}\text { old woollens now } \\
\text { passed on; } \\
\text { Christianity and good } \\
\text { shepherd; lamb part of } \\
\text { every ritual meal } \\
\text { (engagement, } \\
\text { wedding, baptism); } \\
\text { cheese (graviera) } \\
\text { often ditto. }\end{array}$ \\
\hline
\end{tabular}


Fig. 2: Comparative Table for Transhumance in the Pindus Mountains, NW Greece

\begin{tabular}{|c|c|c|c|}
\hline & Wace and Thompson (n. 2) & Sivignon (n. 21) & $\begin{array}{l}\text { Chang and Tourtellotte } \\
\text { (n. 5) }\end{array}$ \\
\hline 1 Environment & & $\begin{array}{l}\text { Village of Avdhela on } \\
\text { ophiolites, with poorer } \\
\text { vegetation and less water. }\end{array}$ & \\
\hline $\begin{array}{l}2 \text { Location/ } \\
\text { movement }\end{array}$ & $\begin{array}{l}\text { semi-nomadic inverse } \\
\text { pastoralism, summer } \\
\text { villages are 'home' but not } \\
\text { everyone comes up in } \\
\text { summer; some stay down in } \\
\text { plains, some are already } \\
\text { emigrating (e.g. to US). }\end{array}$ & $\begin{array}{l}\text { same, oriented to E side of } \\
\text { Pindus. many Vlachs now } \\
\text { sedentary agro- } \\
\text { pastoralists, and some } \\
\text { keep no sheep. }\end{array}$ & $\begin{array}{l}\text { same, with some year- } \\
\text { round residence in } \\
\text { summer village. }\end{array}$ \\
\hline 3 Scale & $\begin{array}{l}\text { trade in wool, cheese, meat, } \\
\text { lumber handled at fairs } \\
\text { attended by Greek and } \\
\text { foreign merchants. }\end{array}$ & $\begin{array}{l}\text { co-operative now handles } \\
\text { trade of textiles (flokatia). }\end{array}$ & $\begin{array}{l}\text { EU money keeps animal } \\
\text { husbandry going; larger } \\
\text { herds now possible in } \\
\text { fields no longer } \\
\text { cultivated. }\end{array}$ \\
\hline 4 Specialisation & textiles; cheese; meat. & textiles; cheese; meat. & textiles?; cheese; meat. \\
\hline 5 Links with agriculture & $\begin{array}{l}\text { summer: every house has } \\
\text { own garden; winter: } \\
\text { cultivation on the plains. }\end{array}$ & $\begin{array}{l}\text { no agriculture in summer } \\
\text { villages; increasing } \\
\text { agriculture on plains. }\end{array}$ & $\begin{array}{l}\text { definitely an agro- } \\
\text { pastoral system, but } \\
\text { details not discussed. }\end{array}$ \\
\hline $\begin{array}{l}6 \text { Gender and division of } \\
\text { labour }\end{array}$ & $\begin{array}{l}\text { women do wool-working; } \\
\text { men tend sheep, mules. }\end{array}$ & $\begin{array}{l}\text { women do wool-working; } \\
\text { men tend sheep (and } \\
\text { vehicles). }\end{array}$ & $\begin{array}{l}\text { ?men primarily } \\
\text { responsible for sheep. }\end{array}$ \\
\hline 7 Cultural integration & $\begin{array}{l}\text { Vlach language spoken and } \\
\text { written; few Greek or }\end{array}$ & $\begin{array}{l}\text { Vlach language no longer } \\
\text { taught in school; more }\end{array}$ & not discussed. \\
\hline
\end{tabular}




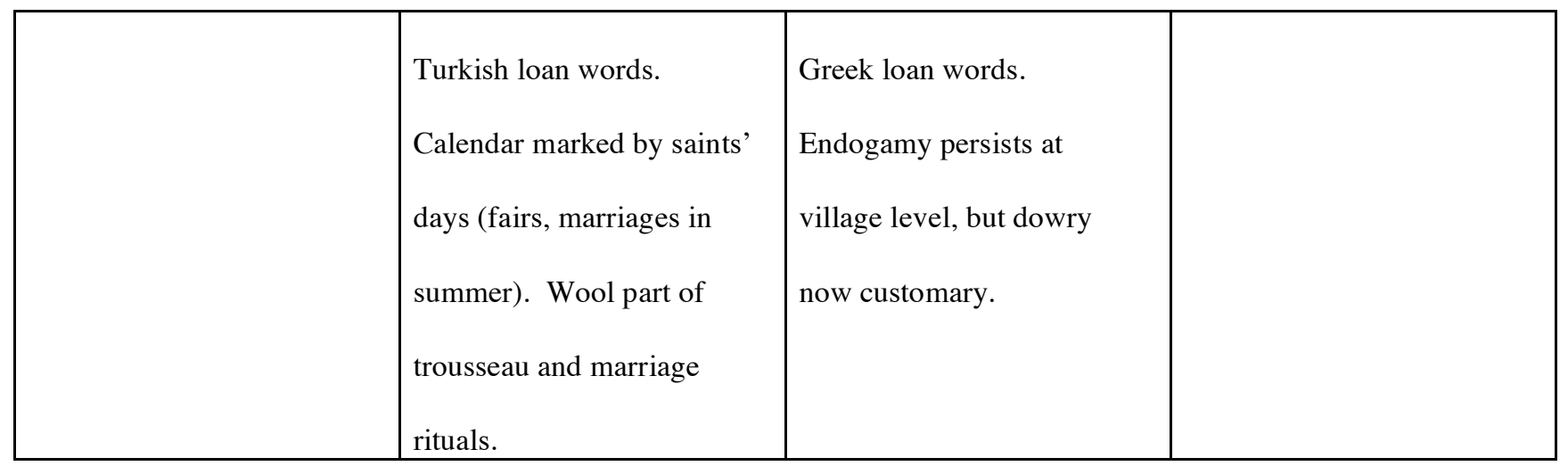


MAP 1

The eparchy (now deme) of Sphakia. The map marks only places mentioned in the text.

MAP 2

The Southern Balkans (Wace and Thompson [n. 2], Map 2 facing p. 206). Avdhela is $15 \mathrm{~km} \mathrm{SE}$ of Samarina. 


\section{FOOTNOTES}

Compendium Footnote for Fig. 1, Sphakia, Crete.

A first version of this chart was made in 1993, when Nixon and Price presented a seminar on transhumance and pastoralism at All Souls College in Oxford. Like the first version, this revised chart includes both evidence collected by the Sphakia Survey, and data from other areas of Crete. The best starting point for the Sphakia Survey is our website (http://sphakia.classics.ox.ac.uk/). The Survey has produced three preliminary reports as well as other articles (cited in n. 17; republished on the website), and unpublished research reports. Rackham and Moody (n. 17) draw heavily on evidence collected by the Sphakia Survey, not all of it published elsewhere. A visual source for transhumant pastoralism in Sphakia is the video made about the project (L. Nixon and S. Price, The Sphakia Survey, Methods and Results (50 minute video) (Educational Technology Resources Centre, 37 Wellington Square, Oxford OX1 2JF; Oxford, 1995).

The Roman numerals i-ii refer to two different options for handling the animals (as explained in Section II): i. localised herding at a permanent settlement (Anopoli); ii. transhumance between Anopoli and the Madhares.

\section{Environment:}

Rackham and Moody (n. 17), 39-41, 123-8, 130.

\section{Location/movement:}

field observations and research reports; Nixon and Moody et al. (n. 17), 256-8; cf. Rackham and Moody (n. 17), 159-64. The shipment of milk to cheese factories elsewhere, and the application of new technologies to old economic activities, are nicely combined in the following mantinada, heard by us in Khania, September 2000:

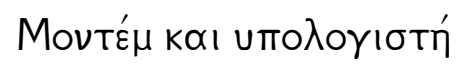

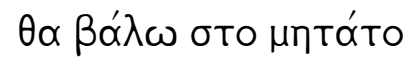

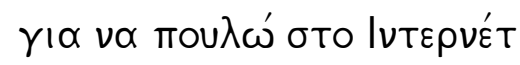




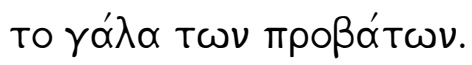

Modem and computer

I'll put in the mitato

So I can sell on the internet

the milk of the sheep.

3. Scale:

PH: Halstead (n. 79).

GACHR: Chaniotis (n. 47).

BVT: Randolph (n. 55), 85, cited above in section III; Nixon and Moody et al. 1990 (n. 17).

20th c.: field observations and research reports.

4. Specialisation:

PH: Killen 1964 (n. 51); Barber (n. 51).

20th c.: field observations and research reports; Nixon and Price 1995 (supra).

5. Links with agriculture:

(B)VT: field observations and research reports.

6. Gender and the division of labour:

PH: Nixon (n. 72).

GACHR: seventh century BC stele with woman spinning from Prinias, A. Lembesi, O $\underline{1}$ oтń $\lambda \varepsilon \varsigma$ Tou Tpıvıá (Ministry of Culture and Sciences Publications Arkhaiologikon Deltion, No. 22; Athens, 1976), A1; cf. A2-3, B10, B12.

(B)VT: research reports.

20th c.: field observations and research reports.

7. Cultural integration: 


\section{GACHR:}

loom, like plough, could not be mortgaged, ICret iv. 75. B3-5 (from Gortyn). Cf. also the Gortyn Law Code on divorce, where the wife could return to her father's house with half of what she had inwoven (cols. ii. 50-2, iii. 26, 36; R. F. Willetts (ed. and transl.), The Law Code of Gortyn (Berlin, 1967), 51).

bronze cut-out votive plaques with man (shepherd?) and ram, one each from Symi and the Idaean Cave: Lembesi (n. 87).

(B)VT and 20th c.: field observations and research reports. 
Compendium footnote for Fig. 2, Pindus.

A more detailed diachronic study of the Pindus would make more use of Weigand (n. 23). But although he does occasionally discuss transhumance, e.g. ibid. i. 132-8 for Avdhela and Perivoli, his focus was more linguistic than economic or material; vol. 2 consists entirely of translated Vlach songs and proverbs, including some also from Samarina (and cf. id., Die Sprache der

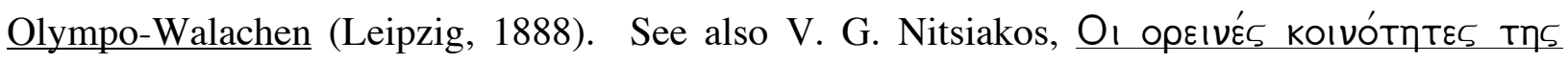

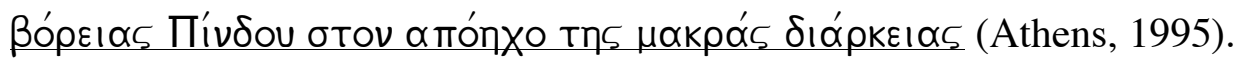

1. Environment: Sivignon (n. 21), 5, 6, 9.

2. Location/movement:

Wace and Thompson (n. 2), 2, 46-7, 291; Sivignon (n. 21), 1, 14, 24, 38; Chang and Tourtellotte (n. 5), 256, 258-9

3. Scale:

Wace and Thompson (n. 2), 12, 71, 76, 79, 82, 84; Sivignon (n. 21), 22; Chang and Tourtellotte (n. 5), 255-6.

4. Specialisation:

Wace and Thompson (n. 2), as for scale; Sivignon (n. 21), 16, 17, 22; Chang and Tourtellotte (n. 5), as for scale.

5. Links with agriculture:

Summer: Wace and Thompson (n. 2), 39, 72, 76; Sivignon (n. 21), 9, 18, 25, 37-9; Chang and Tourtellotte (n. 5), 253.

Winter: Wace and Thompson (n. 2), 45, 46, 75; Sivignon (n. 21), 25.

6. Gender and the division of labour: 
Wace and Thompson (n. 2), 78-84, 95; Sivignon (n. 21), 16-17, 22-3.

7. Cultural integration:

Language: Wace and Thompson (n. 2), 226-55, 285-95 (tale of the Jew and the Shepherd Boy at 294-5); Sivignon (n. 21), 30.

Calendar: Wace and Thompson (n. 2), 11, 48, 85-93; Sivignon (n. 21), 34-5.

Trousseau: Wace and Thompson (n. 2), 110, 119-20. 
About the authors

Lucia Nixon has worked on Crete since 1976, first at Kommos, and since 1987 as co-director of the Sphakia Survey. She has taught archaeology at Magdalen and St Peter's Colleges, Oxford, and is now Senior Tutor of St Hilda's College, Oxford (lucia.nixon@st-hildas.ox.ac.uk). Simon Price teaches ancient history at Lady Margaret Hall, Oxford. He is also project historian for the

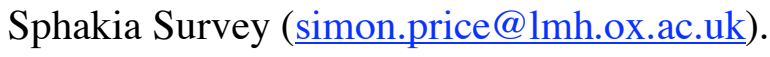


1 This article has arisen out of our work for the Sphakia survey (1987-present). We are most grateful to the Greek Ministry of Culture and Sciences for granting us a permit through the Canadian Archaeological Institute at Athens; to Maria Andreadaki-Vlazaki, Vanna Niniou-Kindeli, and Stavroula Markoulaki of the Khania Ephoreia for facilitating the project at every stage; and to those who have funded the work: principally, the Social Sciences and Humanities Research Council of Canada, the Institute for Aegean Prehistory (New York), and the Craven Committee and the Emergency Research Fund (Oxford). We also owe an immense amount to our principal collaborators on the Sphakia Survey: Jennifer Moody (co-director) and Oliver Rackham (project botanist and historical ecologist). We are also grateful to John Bennet for comments on Linear B material. We thank the many helpful librarians in the Ashmolean and Taylorian Libraries (both the main Taylorian and the Slavonic and Greek Annexe). Finally, we would like to acknowledge the stimulating and evocative setting of Psalm 23 composed by Leonard Bernstein as part of the Chichester Psalms (1965). Sections I - V were written jointly by Nixon and Price, Sections VI and VII by Nixon alone.

2 A. J. B. Wace and M. S. Thompson, The Nomads of the Balkans: An Account of Life and Customs among the Vlachs of Northern Pindus (London, 1914; repr. New York, 1971).

3 J. Klein, The Mesta. A Study in Spanish Economic History 1273-1836 (Cambridge MA, 1920); also P. García Martín, La Mesta (Historia 16; Madrid 1990).

$4 \quad$ A. Bryer and D. Winfield, The Byzantine Monuments and Topography of the Pontos (Washington DC, 1985), 7, 44, 260.

5 S. Xanthoudidis, The Vaulted Tombs of Mesara, transl. J.P. Droop (London, 1924). H. Blitzer, 'Pastoral life in the mountains of Crete', Expedition, 32.3 (1990), 34-41; C. Chang, 'Archaeological landscapes. The ethnoarchaeology of pastoral land use in the Grevena province of 
Greece', in J. Rossignol and L. Wandsnider (eds), Space, Time and Archaeological Landscapes (New York and London, 1992), 65-89; C. Chang and P. A. Tourtellotte, 'Ethnoarchaeological survey of pastoral transhumance sites in the Grevena region, Greece', JFA 20 (1993), 249-64.

6 Spain: O. H. Creighton, and J. R. Segui, 'The ethnoarchaeology of abandonment and postabandonment behaviour in pastoral sites: evidence from Famorca, Alacant Province, Spain', Journal of Mediterranean Archaeology, 11 (1998), 31-52. Italy: G. Barker and A. Grant (eds), 'Ancient and modern pastoralism in central Italy: an interdisciplinary study in the Cicolano mountains', PBSR 59 (1991), 15-88. Turkey: R. Cribb, Nomads in Archaeology (Cambridge, 1991).

7 E.g. N. Efstratiou, 'The archaeology of the Greek uplands: The early Iron Age site of Tsouka in the Rhodope mountains', BSA 88 (1993), 135-71; S. A. Rosen, 'A Roman-period pastoral tent camp in the Negev, Israel', JFA 20 (1993), 441-51.

$8 \quad$ S. Ott, The Circle of Mountains. A Basque Shepherding Community (Oxford, 1981); R. McC. Netting, Balancing on an Alp. Ecological Change and Continuity in a Swiss Mountain Community (Cambridge, 1981).

$9 \quad$ Cf. S. Hodkinson, 'Animal husbandry in the Greek polis', in C. R. Whittaker (ed.), Pastoral Economies in Classical Antiquity (PCPS Supp. 14; Cambridge, 1988), 35-74, at 51-8; H. A. Forbes, 'The identification of pastoralist sites within the context of estate-based agriculture in ancient Greece', BSA 100 (1995), 325-38, at 327.

10 Cf. F. Braudel, The Mediterranean and the Mediterranean World in the Age of Philip II (London, 1972), i. 85-102.

11 P. Halstead, 'Traditional and ancient rural economy in Mediterranean Europe: plus ça change?' JHS 107 (1987), 77-87; id., 'Present to past in the Pindhos: diversification and specialisation in mountain economies', in R. Maggi, R. Nisbet and G. Barker (eds), Archeologia della Pastorizia nell'Europa Meridionale (Rivista di Studi Liguri, 56; Bordighera, 1990), 61-80.

12 Cf. M. Corbier, 'La transhumance entre le Samnium et l'Apulie: continuités entre l'époque républicaine et l'époque impériale', in La romanisation du Samnium au IIe et Ier siècles av. J.-C. (Naples, 1991), 149-76, arguing that Medieval patterns must not be assumed for Roman Italy. 
13 H. A. Forbes, Review of M. Herzfeld, Poetics of Manhood, Liverpool Classical Monthly, 15 (1990), 8-16, at 12-14.

14 Cf. the synthesis of Barker and Grant (n. 6).

15 J. Breuilly, 'Introduction: making comparisons in history', in idem,

Labour and Liberalism in Nineteenth-Century Europe (Manchester and New York, 1992), 1-25. For more detailed introductions to the varying logics of comparative history, see T. Skocpol and M.

Somers, 'The uses of comparative history in macrosocial enquiry', Comparative Studies in Society and History 22 (1980), 174-97; H.-G. Haupt and J. Kocka (eds), Geschichte und Vergleich: Ansätze und Ergebnisse international vergleichender Geschichtsschreibung (Frankfurt/Main and New York, 1996). We are grateful to $\mathrm{Mr} \mathrm{T}$. Weber for some of these references.

16 On the Mediterranean as a whole see J. Boyazoglu and J.-C. Flamant, 'Mediterranean systems of animal production', in J. G. Galaty and D. L. Johnson (eds), The World of Pastoralism: Herding Systems in Comparative Perspective (London and New York, 1990), 353-93.

17 L. Nixon, J. Moody, S. Price and O. Rackham, 'Archaeological survey in Sphakia, Crete', Echos du monde classique/Classical Views (EMC/CV), 32 n.s. 7 (1988), 157-73; 'Archaeological survey in Sphakia, Crete', EMC/CV 33 n.s. 8 (1989), 201-15; 'Archaeological survey in Sphakia, Crete', with V. Niniou-Kindeli, EMC/CV 34 n.s. 9 (1990), 213-20; 'Rural settlement in Sphakia, Crete', in P. Doukellis and L. Mendoni (eds), Structures rurales et sociétés antiques, Actes du colloque de Corfou 14-16 mai 1992 (Annales littéraires de l'Université de Besançon; Paris, 1994), 255-64; J. Moody, L. Nixon, S. Price and O. Rackham, 'Surveying poleis and larger sites in Sphakia', in W. G. Cavanagh and M. Curtis (eds), Post-Minoan Crete: Proceedings of the First Colloquium (BSA Studies 2; London, 1998), 87-95. Cf. also O. Rackham and J. Moody, The Making of the Cretan Landscape (Manchester, 1996), 159-64.

18 See Nixon and Moody et al. 1994 (n. 17), 256-8.

19 The final paper publication of the Sphakia Survey will include a full discussion of pastoralism in Sphakia.

$20 \quad$ Wace and Thompson (n. 2), 2-5, 10-11. 
21 M. Sivignon, 'Les pasteurs du Pinde septentrional', Revue de Géographie de Lyon, 43 (1968), $5-43$

22 Chang (n. 5); Chang and Tourtellote (n. 5).

$23 \quad$ Halstead 1990 (n. 11); H. R. Reinders and W. Prummel, 'Transhumance in Hellenistic Thessaly', Environmental Archaeology, 3 (1998), 81-95. On the Vlachs see further: G. Weigand, Die Aromunen (Leipzig, 1895); T. Winnifrith, The Vlachs: A History of a Balkan People (London, 1987). On the Sarakatsanoi see: J. K. Campbell, Honour, Family and Patronage. A Study of Institutions and Moral Values in a Greek Mountain Community (Oxford, 1964); G. B. Kavadias, Pasteurs-nomades méditerranéens: Les Saracatsans de Grèce (Paris, 1965).

24 E. Benveniste, 'Noms d'animaux en Indo-européen', Bulletin de la Société de Linguistique de Paris, 45 (1949), 74-103, at 91-100; Le vocabulaire des institutions indo-européennes (Paris, 1969), i. $37-45$.

25 J. Blache, L'homme et la montagne (Paris, 1933), 13-41; J. R. McNeill, The Mountains of the Mediterranean World (Cambridge, 1992), 112-14, 276-82.

26 X. de Planhol, De la plaine pamphylienne aux lacs pisidiens. Nomadisme et vie paysanne (Paris, 1958); Cribb (n. 6), 113-32.

27 J. A. Marino, Pastoral Economics in the Kingdom of Naples (Baltimore and London, 1988); G. Barker, et al., A Mediterranean Valley. Landscape Archaeology and Annales History in the Biferno Valley (London and New York, 1995), 34-7.

28 Braudel (n. 10) is not himself committed to non-change in transhumance, though the view is sometimes attributed to him. R. E. Rhoades and S. I. Thompson, 'Adaptive strategies in alpine environments: beyond ecological particularism', American Ethnologist, 2 (1975), 535-51, stress the environment.

29 J. Lewthwaite, 'Plains tails from the hills: transhumance in Mediterranean archaeology', in A. Sheridan and G. Bailey (eds), Economic Archaeology. Towards an Integration of Ecological and Social Approaches (BAR S. 96; Oxford, 1981), 57-66; P. Horden and N. Purcell, The Corrupting Sea: A Study of Mediterranean History (Oxford and Malden MA, 2000), 80-7, 197-200. 
Cf. A. M. Rosen, C. Chang and F. P. Grigoriev, 'Palaeoenvironments and economy of Iron Age Saka-Wusun agro-pastoralists in southeastern Kazakhstan', Antiquity 74 (2000), 611-23. This area has been attractive to pastoralists since the Iron Age 'because of its great environmental diversity within a mere 80 km' (p. 612).

31 E. Le Roy Ladurie, Times of Feast, Times of Famine: A History of Climate since the Year 1000 (London, 1972); Rackham and Moody (n. 17), 38-41, 123-8.

$32 \quad$ Marino (n. 27), 66.

$33 \quad$ McNeill (n. 25), 235-6.

$34 \quad$ Barker and Grant (n. 6).

35 H. A. Forbes, 'European agriculture viewed bottom-side upwards: fodder- and forage-provision in a traditional Greek community', Environmental Archaeology, 1 (1998), 19-34.

36 H. A. Koster, The Ecology of Pastoralism in Relation to Changing Patterns of Land Use in NorthEast Peloponnese (unpublished PhD dissertation; University of Pennsylvania, 1977).

$37 \quad$ Netting (n. 8).

$38 \quad$ Campbell (n. 23).

$39 \quad$ Sivignon (n. 21).

$40 \quad$ Marino (n. 27), 42; Barker and Grant (n. 6), 30; Barker et al. (n. 27), 35 fig. 16.

$41 \quad$ Klein (n. 3).

42 Cf. G. Burgel, Pobia: Etude géographique d'un village Crétois (Athens, 1965), 26-8 on central Crete.

43 Marino (n. 27), 42-3; Barker et al. (n. 27), 34-6. In Spain there were special royal officials to enforce such rulings: Klein (n. 3), 18-22, 88-92.

44 P. Halstead and J. Tierny, 'Leafy hay: an ethnoarchaeological study in NW Greece', Environmental Archaeology, 1 (1998), 71-80.

45 A. M. Khazanov, Nomads and the Outside World (Cambridge, 1984); Hodkinson (n. 9), 51-8;

S. Hodkinson, 'Imperialist democracy and market-oriented pastoral production in classical Athens', Anthropozoologica, 16 (1992), 53-60. 
S. Hodkinson, 'Politics as a determinant of pastoralism: the case of southern Greece, ca. 800300 BC', in Maggi et al. (n. 23), 139-63.

47 A. Chaniotis, "Problems of "pastoralism" and "transhumance" in classical and hellenistic Crete', Orbis Terrarum, 1 (1994), 1-50.

48 M. Corbier, 'Fiscus and patrimonium: the Saepinum inscription and transhumance in the Abruzzi', JRS 73 (1983), 126-31; cf. M. Pasquinucci, 'La transumanza nell' Italia romana', in E. Gabba and Pasquinucci, Strutture agrarie e allevamento transumante nell' Italia romana (III-I sec. a.c.) (Pisa, 1979), 75-182; Barker et al. (n. 27), 244.

49 Klein (n. 3); cf. Braudel (n. 10), i. 91-4; García Martín (n. 3).

50 Cribb (n. 6), 61-2, 135; state-run collectivist farms may organise nomadic pastoralism: C.

Humphrey and D. Sneath (eds), Culture and Environment in Inner Asia, 2 vols (Cambridge, 1996), i. p. 3.

51 J. T. Killen, 'The wool industry of Crete in the late bronze age', BSA 59 (1964), 1-15; id., 'The textile industries at Pylos and Knossos', in C. W. Shelmerdine and T. G. Palaima (eds), Pylos Comes Alive (New York, 1984), 49-63; id., 'Records of sheep and goats at Mycenaean Knossos and Pylos', Bulletin on Sumerian Agriculture, 7 (1993), 209-18; E. Barber, $\underline{\text { Prehistoric Textiles: The Development }}$ of Cloth in the Neolithic and Bronze Ages with Special Reference to the Aegean (Princeton, 1990), 284.

$52 \quad$ P. Halstead, 'Lost sheep? On the Linear B evidence for breeding flocks at Mycenaean Knossos and Pylos', Minos, 25-6 (1993), 343-65.

53 P. Garnsey, 'Mountain economies in southern Europe. Thoughts on the early history, continuity and individuality of Mediterranean upland pastoralism', in Whittaker (n. 9), 196-209. See S. R. Epstein, An Island for Itself: Economic Development and Social Change in Late Medieval Sicily (Cambridge, 1992), 169-76 for the development of this point in relation to late Medieval Sicily and Italy (a reference we owe to Dr N. Stargardt).

54 Alexandria: S. D. Goitein, A Mediterranean Society : The Jewish Communities of the Arab World as Portrayed by the Documents of the Cairo Geniza (Berkeley, 1967-93), i. 46, 124; France and 
Italy: F. Thiriet, La Romanie vénitienne au moyen age (Bibl. des Ecoles françaises d'Athènes et de Rome 193; Paris, 1959), 324.

55 B. Randolph, The Present State of the Islands in the Archipelago (Oxford, 1687), 85.

56 In the second millennium BC in parts of Greece, according to P. Halstead, 'The development of agriculture and pastoralism in Greece: when, how, who and what?', in D. R. Harris (ed.), The Origins and Spread of Agriculture and Pastoralism in Eurasia (London, 1996), 296-309.

57 A. S. Sherratt, 'Plough and pastoralism: aspects of the secondary products revolution', in I. Hodder, G. Isaac and N. Hammond (eds), Patterns of the Past. Studies in Honour of David Clarke (Cambridge, 1981), 261-305. Reprinted in Sherratt, Economy and Society in Prehistoric Europe: Changing Perspectives (Edinburgh, 1996), 158-98. Archaeozoology is an important tool in determining the use made of animals, though its interpretation is sometimes controversial: S. Payne, 'Zoo-archaeology in Greece: a reader's guide', in N. C. Wilkie and W. D. E. Coulson (eds), Contributions to Aegean Archaeology. Studies in Honour of William A. McDonald (Minneapolis, 1985), 211-44; P. Halstead, 'Pastoralism or household herding? Problems of scale and specialization in early Greek animal husbandry', World Archaeology, 28 (1996), 20-42; T. P. O’Connor, 'On the difficulty of dating seasonal slaughtering of sheep', Environmental Archaeology, 3 (1998), 5-11. $58 \quad$ Marino (n. 27), 54-6.

$59 \quad$ Killen 1964 (n. 51) and 1984 (n. 51).

60 Quoted in C. Chang and H. A. Koster, 'Beyond bones: toward an archaeology of pastoralism', in M. B. Schiffer (ed.), Advances in Archaeological Method and Theory 9 (New York, 1986), 97-148, at 98 .

$61 \quad$ Cribb (n. 6), 15-18.

$62 \quad \operatorname{Koster}($ n. 36); Sherratt (n. 57); Hodkinson (n. 9); Forbes (n. 35); L. Foxhall, 'Snapping up the unconsidered trifles: the use of agricultural residues in ancient Greek and Roman farming', Environmental Archaeology, 1 (1998), 35-40.

63 Cribb (n. 6), 23-7. 
For other examples of pastoral and agricultural calendars see Barker and Grant (n. 6), fig.8 (on Cicolano mountains of central Italy); Campbell (n. 23), 19-24 (on pastoral year of the Sarakatsanoi of northern Greece); S. Greger, Village on the Plateau. Magoulas, a Mountain Village in Crete (Studley, Warwickshire, 1988), 55 (on Lasithi plateau of Crete); McNeill (n. 25), 113 (on Taurus mountains); Marino (n. 27), 40-2, 53-4 (on Abruzzi-Puglia); below, section VII.

$65 \quad$ Koster (n. 36), 240-1; Lewthwaite (n. 29).

66 S. E. Alcock, J. F. Cherry and J. L. Davis, 'Intensive survey, agricultural practices and the classical landscape of Greece', in I. Morris (ed.), Classical Greece: Ancient Histories and Modern Archaeologies (Cambridge, 1994), 137-70; A. Snodgrass, 'Response: the archaeological aspects', ibid., 197-200, at 199-200.

$67 \quad$ Marino (n. 27), 43-4.

$68 \quad$ Ibid. $58-60$.

69 Cf. Chang and Koster (n. 60), 103 on Greece.

70 E. Brumfiel, 'Weaving and cooking: women's production in Aztec Mexico', in J. M. Gero and M. Conkey (eds), Engendering Archaeology. Women in Prehistory (Oxford, 1991), 224-51; M. Conkey, 'Contexts of action, contexts for power: material culture and gender in the Magdalenian', ibid., 57-92; J. Gero, ‘GenderLithics: women’s roles in stone tool production’, ibid., 163-93. 71 Above, section V; cf. also C. Oxby, 'The involvement of agropastoralist women in livestock programmes', in T. Wallace (ed., with C. March), Changing Perceptions: Writings on Gender and Development (Oxford, 1991), 202-09; C. Watson, 'Turkana women: their contribution in a pastoralist society', ibid., 193-201.

72 L. Nixon, 'Women, children and weaving', in P. P. Betancourt, V. Karageorghis, R. Laffineur, and W.-D. Niemeier (eds), Meletemata. Studies in Aegean Archaeology Presented to Malcolm H.Wiener as he Enters his 65th Year (Aegaeum, 20; Liège and Austin TX, 1999), 561-7.

73 Wace and Thompson (n. 2), 78-84, 95, 119-20, and pls. 12 and 13a.

$74 \quad$ Sivignon (n. 21), 22.

$75 \quad$ Ibid 22. 
76 Chang and Tourtellotte (n. 5); the same applies to Chang (n. 5).

77 Basically, women spin and weave; they also do some finishing of woven cloth, but it seems that only men are fullers. Killen 1964 (n. 51); id., 'The Knossos Ld (1) tablets', in E. Risch and H. Mühlstein (eds), Colloquium Mycenaeum. Actes du Sixième Colloque International sur les textes mycéniens et égéens tenu à Chuamont sur Neuchâtel du 7 au 13 Sept. 1975 (Geneva, 1979), 151-81 at 160 and n. 30; id. 1984 (n. 51); Barber (n. 51), 283; T. G. Palaima, 'Potter and fuller: the royal craftsmen', in R. Laffineur and P. P. Betancourt (eds), TEXNH. Craftsmen, Craftswomen and Craftsmanship in the Aegean Bronze Age (Aegaeum 16; Liège and Austin TX, 1997), 407-12 (mentioning a royal male fuller, and royal male purple dye-workers).

78 Nixon (n. 72), 564-7, gives the argument; see also Killen 1984 (n. 51), 49-52; id., 'Epigraphy and interpretation in the Knossos WOMAN and CLOTH records', in J.-P. Olivier and T. G. Palaima (eds), Texts, Tablets and Scribes: Studies in Mycenaean Epigraphy and Economy Offered to Emmett L. Bennett, Jr. (Minos Supp. 10, Salamanca, 1988), 167-83; J. Chadwick, 'The women of Pylos', ibid., 43-5; Palaima (n. 77).

79 P. Halstead, 'The Mycenaean palatial economy: Making the most of the gaps in the evidence', PCPS 38 (1992), 57-86. Killen pers. comm. notes that there is evidence for weavers whom the centres did not control directly, provided by the commodity *146 on the Pylos Ma tablets, which is almost certainly a linen fabric. This cloth was not produced under palace direction, but acquired by the palace though the taxation system. There is no evidence about the sex of these weavers. Nixon (n. 72 ), 566 and n. 16.

80 J. Harvey, Traditional Textiles of Central Asia (London, 1996), 47-8, with memorable photograph of a bearded Kohistani man spinning fleece with a drop spindle.

81 O. M. Radostits, D. C. Blood, and C. C. Gray, Veterinary Medicine. A Textbook of the Diseases of Cattle, Sheep, Pigs, Goats, and Horses (8th edn; London, 1994); M. Antoniou, Y. Tselentis, T. Babalis, A. Gikas, N. Stratigakis, I. Vlachonikolis, A. Kafatos, and M. Fioretos, 'The seroprevalence of ten zoonoses in two villages of Crete, Greece [Tymbaki and Anogeia]', European Journal of Epidemiology, 11.4 (1995), 415-23. 
82 For photographs of women actively engaged in agricultural tasks in traditional Greece, see K.

Trantalidou, 'Agriculture, animal husbandry, hunting, fishing', in G. A. Papathanassopoulos (ed.), Neolithic Culture in Greece (Athens, 1996), 95-101, at figs 30 (winnowing), 31 (pounding pulses), 33 (ploughing), and I. Tzachili, 'Weaving - basketry', ibid. 137-9, at figs. 38

(sheep-shearing) 39 (spinning).

$83 \quad$ Halstead (n. 57), 35.

84 A. Peatfield, 'Rural ritual in Bronze Age Crete: the peak sanctuary at Atsipadhes', Cambridge Archaeological Journal, 2 (1992), 59-87, at 72, 78-9.

85 M. Jost, Sanctuaires et cultes d'Arcadie (Paris, 1985), 439-49.

86 P. Borgeaud, The Cult of Pan in Ancient Greece (Chicago and London, 1988), 48-52; Jost (n. $85), 467-70$.

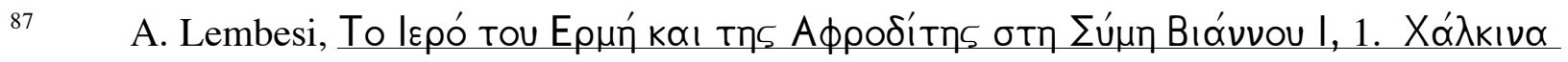

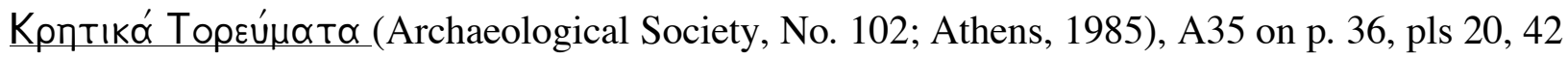
(Symi); G14 on pp. 56-7, pls 27, 42 (Idaean Cave); p. 229. Also a bronze statuette of a man carrying a ram from a sanctuary in the Samaria Gorge: V. Niniou-Kindeli, Kritiki Estia, 4 (1991-93), 231-3. 88 M. Andreadaki-Vlasaki, The County of Khania through its Monuments (Athens, 1997), 59, 6061.

89 These remarks draw on the paper by L. Nixon, 'Sacred Landscapes in early modern Greece: Outlying Churches and Icon Stands in Sphakia SW Crete', presented at the conference The Work of Memory, Swansea, June 2000. A longer version will be submitted for publication.

90 M. H. Jameson, 'Sacrifice and animal husbandry in classical Greece', in Whittaker (n. 9), 87119 , at 102-3.

$91 \quad$ Wace and Thompson (n. 2), 48.

92 Wace and Thompson (n. 2), 48, 77; Campbell (n. 23), 343-4; S. Georgoudi, 'Quelques problèmes de la transhumance dans la Grèce ancienne', $\underline{\text { REG }} 87$ (1974), 155-85, at 169 n.54; in Italy two festivals of S. Michael, 8 May and 29 September: Marino (n. 27), 40, 44. 
93 O. Murray, 'The idea of the shepherd king from Cyrus to Charlemagne', in P. Godman and O. Murray (eds), Latin Poetry and the Classical Tradition (Oxford, 1990), 1-14, at 6.

$94 \quad$ Ibid. 7.

$95 \quad$ Cf. ibid. 5.

96 E.g. A. Appadurai (ed.), The Social Life of Things: Commodities in Cultural Perspective (Cambridge, 1986).

97 J. T. Killen, 'Thebes sealings, Knossos tablets and Mycenaean state banquets', Bulletin of the Institute of Classical Studies, 39 (1994), 67-84.

98 Jameson (n. 90), 90-3. Fleeces do not themselves seem to have been a major pastoral product in the Bronze Age, but they may have had a special, restricted use for ceremonial wear, e.g. the 'priestess' from the West House at Akrotiri may be wearing a fleece garment (S. A. Immerwahr, Aegean Painting in the Bronze Age (University Park PA, 1990), pl. 21); and some of the men and women involved in sacrifice on Sides A and B of the Hagia Triada sarcophagus wear fleecy-looking kilts or skirts (ibid. pls. 50, 51). Actual hides in Linear B are ox-hides where careful account of them was kept (C. W. Shelmerdine, 'Review of Aegean prehistory VI. The palatial Bronze Age of the southern and central Greek mainland', AJA 101 (1997), 537-85, at 567 and n. 186); their final use was not recorded but leather is only the most obvious. Aegean wall-paintings show spotted animals, garments, and objects made from (ox-)hides, e.g. sacrifical bovines co-occurring with the fleeces on the Hagia Triada sarcophagus; bulls from Mycenae (Immerwahr ibid. pl. 16); figure-of eight shields from several sites (Tiryns, Immerwahr ibid. pl. 19); a ship's cabin from Thera (Immerwahr ibid. pl. 15); and a chariot box on the Hagia Triada Sarcophagus (Immerwahr ibid. pl. 52).

That hides had value is confirmed, for example, by the fifth century BC inscription for the appointment of a priestess for the Temple of Athene Nike on the Akropolis at Athens, whose salary included money, plus legs and hides from public sacrifices (ML no. $44=\underline{\mathrm{IG}^{3}} \mathrm{I}^{35}$ ). In the fourth century BC the taxes on upwards of 850 oxen sacrificed annually at Athens were a significant element 
in state revenues (V. J. Rosivach, The System of Public Sacrifice in Fourth-Century Athens (American Classical Studies 34; Atlanta GA, 1994).

$99 \quad$ N. Gavrielides, 'Name days and feasting: social and ecological implications of visiting patterns in a Greek village of the Argolid', Anthropological Quarterly, 47 (1974), 48-70.

100 M. Herzfeld, The Poetics of Manhood. Contest and Identity in a Cretan Mountain Village (Princeton NJ, 1985), 163-205.

101 B. D. Shaw, “Eaters of flesh, drinkers of milk”: the ancient Mediterranean ideology of the pastoral nomad', Ancient Society, 13-14 (1982-83), 5-31, repr. in id., Rulers, Nomads, and Christians in Roman North Africa (Aldershot, Hampshire and Brookfield VA, ca 1995), ch.VI.

102 Sherratt (n. 57).

103 Barber (n. 51), 314-30.

$104 \quad$ Shelmerdine (n. 98), 562.

$105 \quad$ Barber (n. 51), 358-82.

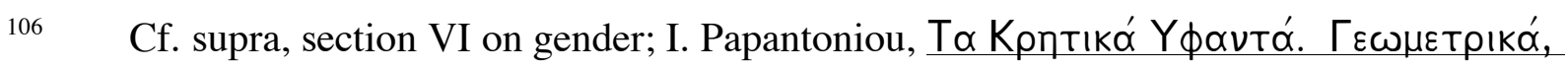

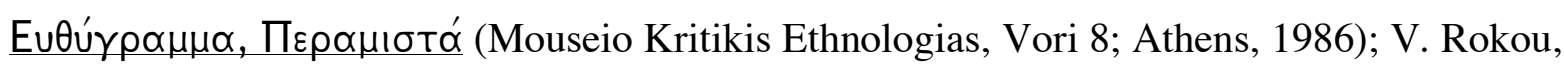

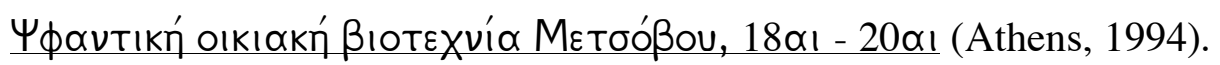

107 Sherratt (n. 57), 276-7; id., 'The secondary exploitation of animals in the Old World', in Sherratt 1996 (n. 57), 199-228, at 205-8.

$108 \quad$ Murray (n. 93), 3.

109 Cf. again Shaw (n. 101). B. D. Shaw, 'Fear and loathing: the nomad menace and Roman Africa', in C. M. Wells (ed.), Roman Africa/L'Afrique romaine (Revue de l'Université d'Ottawa 52; Ottawa, 1982), 25-46 (repr. in id. Rulers, Nomads, and Christians in Roman North Africa (Aldershot, Hampshire and Brookfield VA, ca 1995), ch.VII), shows that the actual relationship between nomads and the settled population in Roman north Africa was one of symbiosis.

110 C. Chang, 'Pastoral transhumance in the southern Balkans as a social ideology:

ethnoarchaeological research in northern Greece', American Anthropologist, 95 (1993), 687-703.

$111 \quad$ Murray (n. 93), 4. 
112 M. L. West, The East Face of Helicon: West Asiatic Elements in Early Poetry and Myth (Oxford, 1997).

113 Cf. R. G. A. Buxton, 'Imaginary Greek mountains', JHS 112 (1992), 1-15, and id., Imaginary Greece: The Contexts of Mythology (Cambridge, 1994), 81-96.

114 G. Morgan, 'Cretan poetry: sources and inspiration', Kr. Chron. 14 (1960), 7-68, 203-70, 379-

434, at 9-43 (repr. Heraklion, 1960); Herzfeld (n. 100), 26-33.

$115 \quad$ Chang and Tourtellotte (n. 5).

116 Wace and Thompson (n. 2), 4, 53-58, 153-6.

117 Ibid. 50. 